Argonne

\title{
Assessment of Light-Duty Plug-In Electric Vehicles in the United States, 2010-2018
}

Energy Systems Division 


\begin{abstract}
About Argonne National Laboratory
Argonne is a U.S. Department of Energy laboratory managed by UChicago Argonne, LLC under contract DE-AC02-06CH11357. The Laboratory's main facility is outside Chicago, at 9700 South Cass Avenue, Lemont, Illinois 60439. For information about Argonne and its pioneering science and technology programs, see www.anl.gov.
\end{abstract}

\title{
DOCUMENT AVAILABILITY
}

Online Access: U.S. Department of Energy (DOE) reports produced after 1991 and a growing number of pre-1991 documents are available free via DOE's SciTech Connect (http://www.osti.gov/scitech/).

Reports not in digital format may be purchased by the public from the National Technical Information Service (NTIS):

U.S. Department of Commerce

National Technical Information Service

5301 Shawnee Road

Alexandria, VA 22312

www.ntis.gov

Phone: (800) 553-NTIS (6847) or (703) 605-6000

Fax: (703) 605-6900

Email: orders@ntis.gov

Reports not in digital format are available to DOE and DOE contractors from:

U.S. Department of Energy

Office of Scientific and Technical Information

P.O. Box 62

Oak Ridge, TN 37831-0062

\footnotetext{
Disclaimer

This report was prepared as an account of work sponsored by an agency of the United States Government. Neither the United States Government nor any agency thereof, nor UChicago Argonne, LLC, nor any of their employees or officers, makes any warranty, express or implied, or assumes any legal liability or responsibility for the accuracy, completeness, or usefulness of any information, apparatus, product, or process disclosed, or represents that its use would not infringe privately owned rights. Reference herein to any specific commercial product, process, or service by trade name, trademark, manufacturer, or otherwise, does not necessarily constitute or imply its endorsement, recommendation, or favoring by the United States Government or any agency thereof. The views and opinions of document authors expressed herein do not necessarily state or reflect those of the United States Government or any agency thereof, Argonne National Laboratory, or UChicago Argonne, LLC.
} 


\section{Assessment of Light-Duty Plug-In Electric Vehicles in the United States, 2010-2018}

by

David Gohlke and Yan Zhou

Energy Systems Division, Argonne National Laboratory

March 2019 
4 


\section{CONTENTS}

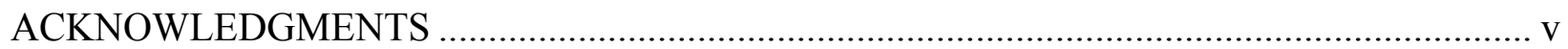

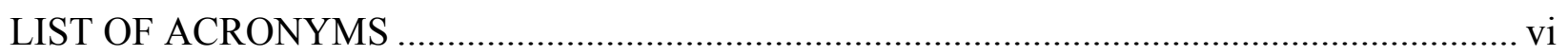

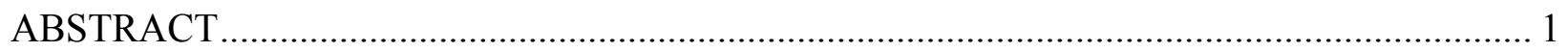

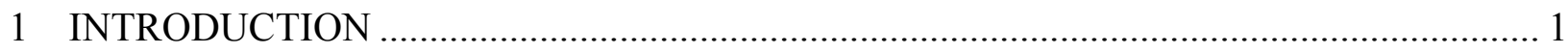

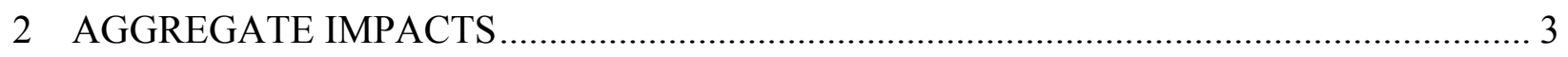

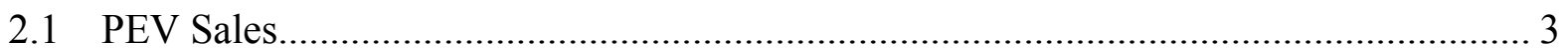

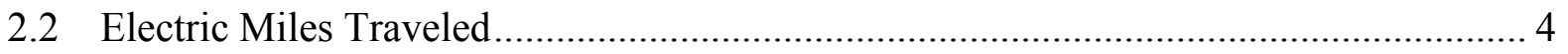

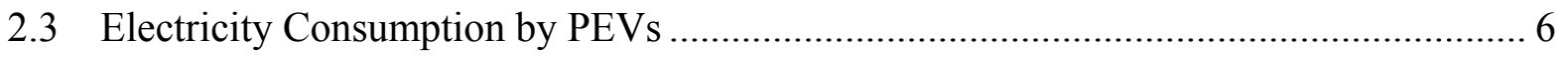

2.4 Gasoline Consumption Reduction ..................................................................... 7

2.5 Carbon Dioxide Emissions .............................................................................. 8

2.6 National-Scale Comparisons ............................................................................. 9

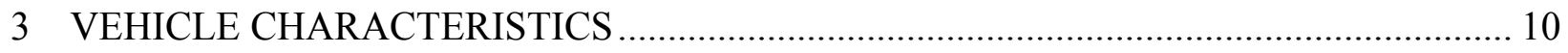

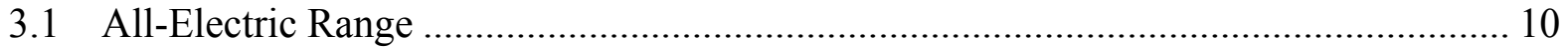

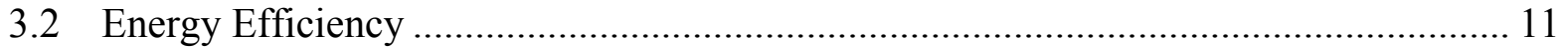

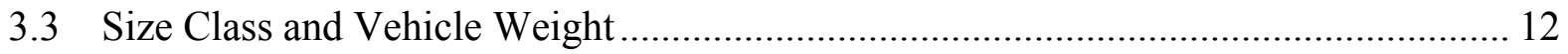

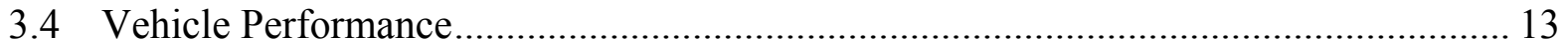

3.5 Vehicle Manufacturing and Assembly............................................................. 14

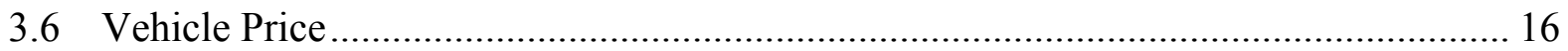

3.7 Battery Capacity and Cathode Chemistry …....................................................... 17

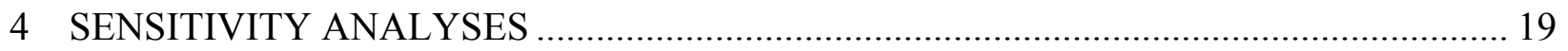

4.1 Traveler Behavior ......................................................................................... 19

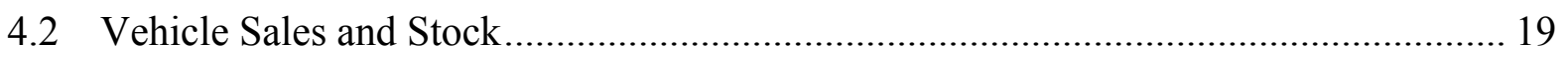

4.3 Comparable ICE Vehicles.................................................................................... 21

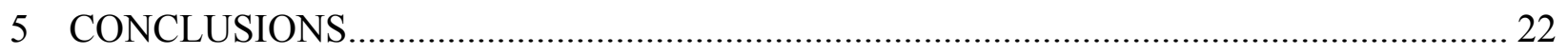

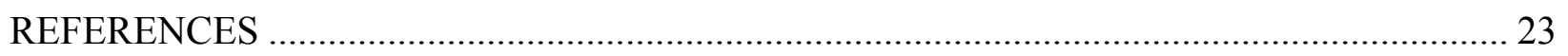




\section{FIGURES}

1 Annual sales of PEVs in the United States by year ........................................................... 3

2 Sales shares of PEVs in the United States by manufacturer ..................................................... 4

3 Electric vehicle miles traveled by light-duty vehicles by year ............................................. 5

4 Electric vehicle miles traveled by LDVs by year .................................................................. 6

5 Electricity consumption by PEVs by year ..................................................................... 7

6 Gasoline displacement from ICE vehicles by LDV PEVs by year........................................ 8

7 Fraction of key national metrics which are due to PEVs in the United States by year ............ 9

8 All-electric range for PEVs. Left side: new vehicles sold in each month.

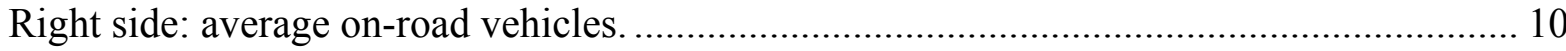

9 Electric efficiency for PEVs. Left side: new vehicles sold in each month.

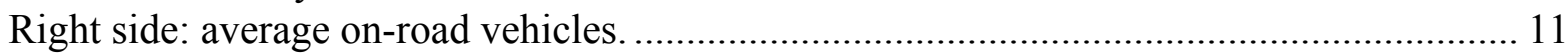

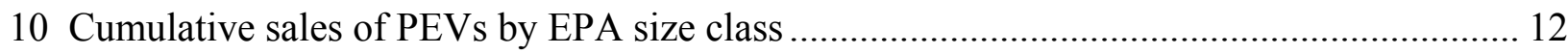

11 Average performance indicators for PEVs sold in each month ............................................. 13

12 Assembly location for PEVs sold in the United States through 2018 .................................. 14

13 Assembly location by month and annual sales-weighted AALA domestic content for PEVs sold in the United States from 2010 to 2018 ........................................... 15

14 Average MSRP for PEV sold from 2010 to 2018; average transaction price for light-duty vehicles included for comparison................................................................... 16

15 Battery capacity added each year for LDV PEVs in the United States ................................. 18

\section{TABLES}

1 Annual Sales of New PEVs, and Total Annual eVMT, Gasoline Reduction, Electricity Consumption, and $\mathrm{CO}_{2}$ Emissions Reduction by On-Road PEVs ......................... 2

2 Comparison of Total Gasoline Reduction and $\mathrm{CO}_{2}$ Emissions Reduction with Different ICE Vehicles for Comparison

3 Annual Sales of New PEVs, and Total Annual eVMT, Gasoline Reduction, Electricity Consumption, and $\mathrm{CO}_{2}$ Emissions Reduction by On-Road PEVs (Duplication of Table 1) 


\section{ACKNOWLEDGMENTS}

This activity was supported by the Vehicle Technologies Office, Office of Energy Efficiency and Renewable Energy, United States Department of Energy. The authors would like to thank Rachael Nealer, Heather Croteau, Kate McMahon, and Jacob Ward for guidance and feedback, and Linda Gaines and Qiang Dai for technical input.

This report was prepared as an account of work sponsored by an agency of the United States government. Neither the United States government nor any agency thereof, nor any of their employees, makes any warranty, express or implied, or assumes any legal liability or responsibility for the accuracy, completeness, or usefulness of any information, apparatus, product, or process disclosed or represents that its use would not infringe privately owned rights. Reference herein to any specific commercial product, process, or service by trade name, trademark, manufacturer, or otherwise does not necessarily constitute or imply its endorsement, recommendation, or favoring by the United States government or any agency thereof. The views and opinions of authors expressed herein do not necessarily state or reflect those of the United States government or any agency thereof. 


\section{LIST OF ACRONYMS}

$\begin{array}{ll}\text { AALA } & \text { American Automobile Labeling Act } \\ \text { BEV } & \text { Battery Electric Vehicle } \\ \text { DOE } & \text { Department of Energy } \\ \text { EPA } & \text { Environmental Protection Agency } \\ \text { eVMT } & \text { electric vehicle miles traveled } \\ \text { FHWA } & \text { Federal Highway Administration } \\ \text { gWh } & \text { gigawatt-hour } \\ \text { ICE } & \text { internal combustion engine } \\ \text { kWh } & \text { kilowatt-hour } \\ \text { LDV } & \text { light-duty vehicle } \\ \text { MDIUF } & \begin{array}{l}\text { Multi-Day Individual Utility Factor } \\ \text { miles per gallon } \\ \text { MPGe } \\ \text { mph }\end{array}\end{array}$




\title{
ASSESSMENT OF LIGHT-DUTY PLUG-IN ELECTRIC VEHICLES IN THE UNITED STATES, 2010 - 2018
}

\begin{abstract}
This report examines properties of plug-in electric vehicles (PEVs) sold in the United States from 2010 to 2018, exploring vehicle sales, miles driven, electricity consumption, petroleum reduction, vehicle manufacturing, and battery production, among other factors. Over one million PEVs have been sold, driving over 25 billion miles on electricity since 2010 , thereby reducing national gasoline consumption by $0.23 \%$ in 2018 and 950 million gallons cumulatively through 2018. In 2018, PEVs used 2.8 terawatt-hours of electricity to drive 8.6 billion miles, offsetting 320 million gallons of gasoline. The majority of these vehicles were assembled in the United States, and over 42 gigawatt-hours of lithium-ion batteries have been installed in vehicles.
\end{abstract}

\section{INTRODUCTION}

While traditional gasoline- and diesel-powered internal combustion engines (ICE) are the most common light-duty drivetrain worldwide, alternative-fuel drivetrains are rapidly increasing in market share. The sales of plug-in electric vehicles (PEVs) are among the fastest growing market shares worldwide, with over one million in operation in each of China, Europe, and the United States (DOE, 2018; Irle, 2018; EV Volumes, 2017). PEVs get at least a portion of their energy from electricity which is supplied to the vehicle through a charging cable. There are two types of PEVs: battery electric vehicles (BEVs) are powered exclusively by electricity, while plug-in hybrid electric vehicles (PHEVs) have a battery as well as a separate gasoline engine for extended driving range.

Understanding the aggregate impact of electric vehicles is important when exploring electricity use and petroleum consumption. Electric utilities are working to understand the changes in electricity generation, demand, and required infrastructure (EEI, 2017; SEPA, 2017). The growth of electric vehicles can offset petroleum consumption by conventional internal combustion engine vehicles, affecting oil prices and extraction (OPEC, 2018). Refineries need to know the potential impact on demand for their refining mix; gasoline and diesel are the two most common end products in the United States (DOE, 2017). This report assesses these impacts, updating a report written last year, "Impacts of Electrification of Light-Duty Vehicles in the United States, 2010 - 2017" (Gohlke and Zhou, 2018). Much of the methodology is similar, though estimations have been updated with improved data when possible.

Table 1 summarizes the high-level national impacts of these plug-in electric vehicles for PEV sales, electric vehicle miles traveled (eVMT), gasoline displacement, electricity consumption, and reductions in carbon dioxide emissions. These quantities have all grown since 
2011. Through 2018, over one million PEVs have been sold in the United States and have driven 25 billion miles, displacing nearly 1 billion gallons of gasoline and 4 million metric tons of $\mathrm{CO}_{2}$, and consuming over 8 terawatt-hours of electricity.

TABLE 1 Annual Sales of New PEVs, and Total Annual eVMT, Gasoline Reduction, Electricity Consumption, and $\mathrm{CO}_{2}$ Emissions Reduction by On-Road PEVs

\begin{tabular}{cccccc}
\hline Year & $\begin{array}{c}\text { PEV sales } \\
\text { (thousands) }\end{array}$ & $\begin{array}{c}\text { eVMT } \\
\text { (billion miles) }\end{array}$ & $\begin{array}{c}\text { Gasoline } \\
\text { reduction } \\
\text { (million gallons) }\end{array}$ & $\begin{array}{c}\text { Electricity } \\
\text { consumption } \\
\text { (gigawatt-hours) }\end{array}$ & $\begin{array}{c}\mathrm{CO}_{2} \text { emissions } \\
\text { reduction } \\
\text { (million metric tons) }\end{array}$ \\
\hline 2011 & 18 & 0.1 & 2 & 20 & 0.01 \\
2012 & 53 & 0.3 & 12 & 110 & 0.05 \\
2013 & 97 & 1.0 & 37 & 330 & 0.17 \\
2014 & 119 & 1.9 & 72 & 650 & 0.33 \\
2015 & 114 & 3.0 & 110 & 1,000 & 0.53 \\
2016 & 160 & 4.3 & 160 & 1,400 & 0.77 \\
2017 & 196 & 6.0 & 230 & 2,000 & 1.10 \\
2018 & 361 & 8.6 & 320 & 2,800 & 1.60 \\
\hline Total & $\mathbf{1 , 1 1 0}$ & $\mathbf{2 5 . 1}$ & $\mathbf{9 5 0}$ & $\mathbf{8 , 4 0 0}$ & $\mathbf{4 . 5 0}$ \\
\hline
\end{tabular}

The data used in this assessment is compiled largely from publicly available data. Compiling data on vehicle sales and characteristics allows for a comprehensive assessment of the historical impacts of PEVs in the United States. Sales estimates for this analysis come from Argonne National Laboratory (ANL, 2019). The all-electric range, vehicle efficiency, size class, electric motor power, and manufacturer's suggested retail price (MSRP) of each model come from the FuelEconomy.gov database, managed by the U.S. Department of Energy (DOE) and Environmental Protection Agency (EPA) (DOE and EPA, 2019). Vehicle assembly and origin of parts come from American Automobile Labeling Act (AALA) data from the National Highway Traffic Safety Administration (NHTSA) (NHTSA, 2018), and are supplemented by manufacturer press releases and news stories. Vehicle acceleration and battery capacity for each vehicle were established through a mix of data compiled by InsideEVs (Kane, 2018), press releases, news stories, and information on manufacturer websites.

Section 2 of this report highlights national scale impacts of the electric vehicle fleet. Section 3 explores how characteristics of PEVs have evolved over time. Section 4 presents a detailed sensitivity analysis on several assumptions, including vehicle sales, battery size, and driving behavior, to test the robustness of the results. Section 5 summarizes key findings in this report. 


\section{AGgREGATE IMPACTS}

This section presents total national-scale metrics for PEVs, including vehicle sales, miles traveled, electricity consumed, gasoline displacement and carbon dioxide emissions. These numbers are then placed in a broader national context to show the impacts of PEVs.

\subsection{PEV SALES}

More than one million PEV have been sold in the United States since 2011. In 2011, fewer than 20,000 PEVs were sold in the United States, while in 2018, more than that were sold each month. Over 360,000 plug-in electric vehicles were sold in the United States in 2018, an $85 \%$ increase over 2017. This growth in PEV sales is shown in Figure 1. Through 2018, a total of more than 1,100,000 PEVs have been sold, slightly over half of which have been BEV. Before 2018, cumulative sales of PHEVs were slightly higher than of BEVs. In 2018, growth in BEV sales, particularly the Tesla Model 3, led to BEVs comprising 65\% of the PEV market.

\section{Annual PEV Sales}

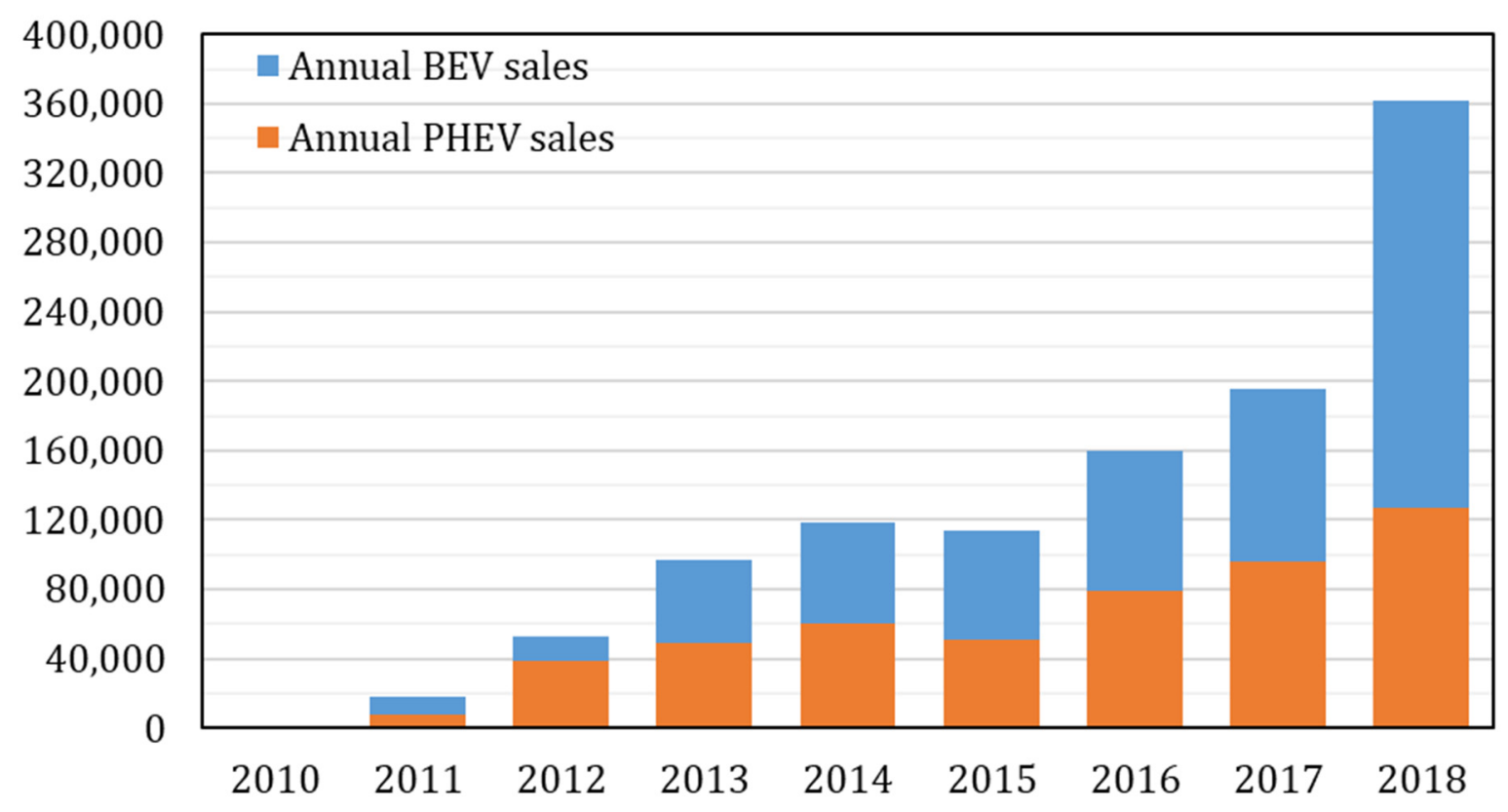

FIGURE 1 Annual sales of PEVs in the United States by year

From 2011 to 2018, annual PEV sales grew from fewer than 18,000 to more than 360,000 , a twenty-fold gain, equivalent to a year-over-year growth rate of $54 \%$. In all but one year (2015), PEV sales in the United States increased. In 2018, 2.1\% of the total national sales of new light-duty vehicles were PEVs (DOE, 2019). As of 2018, ten models of plug-in electric vehicles have sold more than 20,000 units in the United States: Chevrolet Volt, Tesla Model S, 
Tesla Model 3, Nissan Leaf, Toyota Prius, Tesla Model X, Ford Fusion Energi, Chevrolet Bolt, Ford C-Max Energi, and the BMW i3. Of these, the Volt, Model S, Model 3, and Leaf have all sold more than 100,000 units. Sales of the Tesla Model 3 grew rapidly; more than 100,000 vehicles were sold in 2018 alone, and the Model 3 was the top-selling PEV in each month in 2018 .

Figure 2 shows the percentage of all PEV sales by each automaker. Tesla, with 3 models in the overall top ten of U.S. sales, has the most sales with $32 \%$ of all of PEVs. General Motors, Nissan, and Ford also each have at least $10 \%$ of domestic PEV sales.

\section{PEV sales shares by automaker}

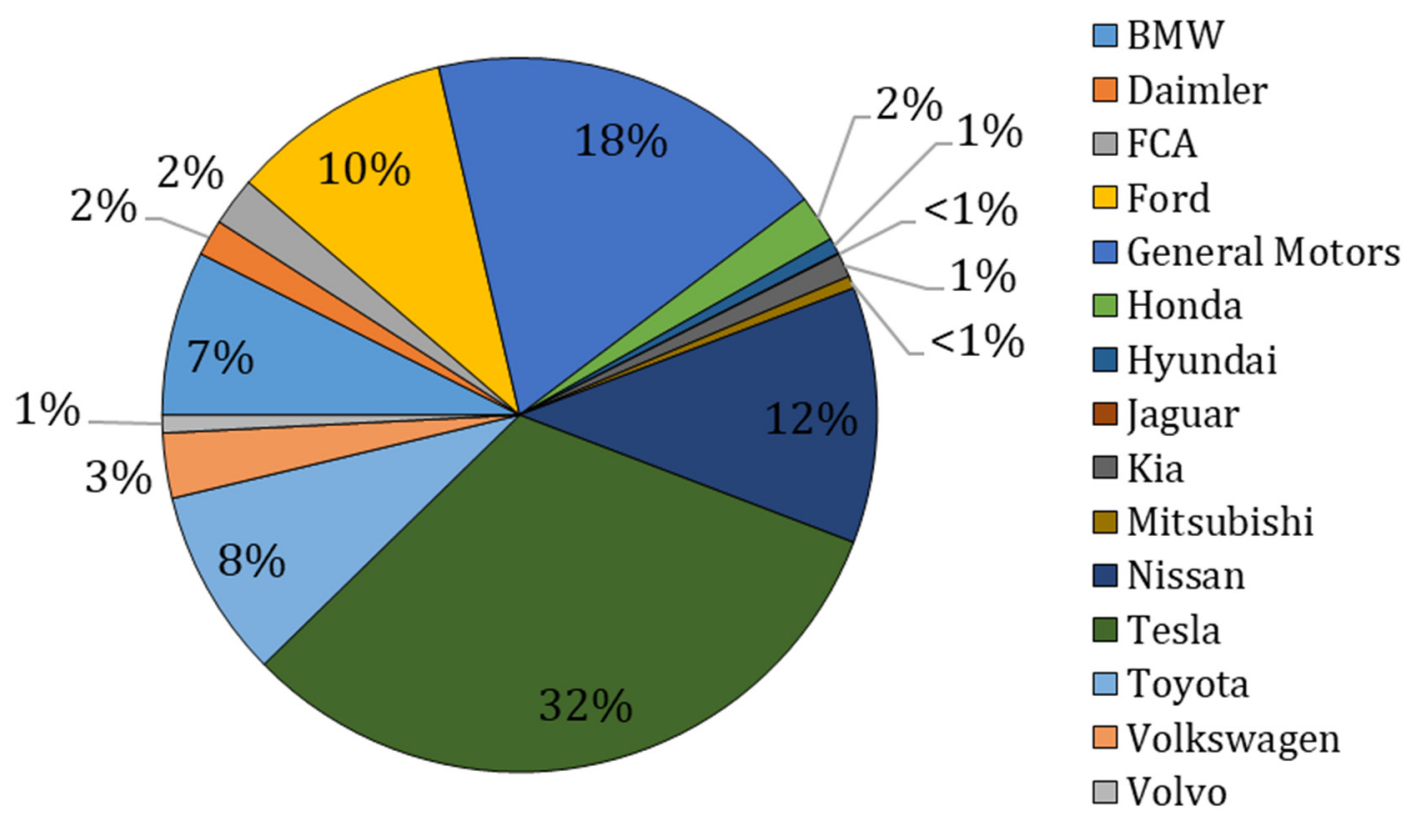

FIGURE 2 Sales shares of PEVs in the United States by manufacturer

\subsection{ELECTRIC MILES TRAVELED}

The total annual vehicle miles traveled (VMT) for each PEV depends on traveler behavior and the vehicle's all-electric range. In this analysis, PHEVs are assumed to drive the same annual distance as similar ICE vehicles, while the total mileage of each BEV is reduced to account for a limited driving range. To determine the driving behavior of similar ICE vehicles, we note that since PEVs are an emerging technology, these vehicles are on average newer than the average ICE vehicle. As of December 2018, the average age of an on-road electric vehicle was 2.5 years old. According to mileage schedules from NHTSA and the EPA (Lu, 2006; EPA, 2016; NHTSA and EPA, 2018) and results from the National Household Travel Survey (Santos et al., 2011; McGuckin and Ford, 2018), the average ICE car is driven approximately 13,00014,000 miles per year in its first three years. Therefore, as a baseline for this report, an annual driving distance of 13,500 miles per vehicle is used. 
Because of the flexibility of a secondary fuel source, PHEVs are assumed to drive the same total distance as ICE vehicles, i.e., 13,500 miles per year. To test this hypothesis, data was pulled from the 2017 National Household Travel Survey (NHTS), which includes self-reported vehicle mileages and best estimates of annual driving. Using NHTS's "bestmile" estimation (FHWA, 2018a), 441 PHEVs from model years (MY) 2011 to 2017 were clearly identifiable, and these vehicles were found to drive on average $97 \%$ as far as the average (non-PEV) car in the NHTS data set from each model year.

PHEVs can travel using a mix of gasoline and electricity. For PHEVs, the utility factor represents the fraction of total mileage run on electricity rather than gasoline. This utility factor is a function of the battery size; a battery with a longer all-electric range will have a higher fraction of miles driven using electricity. The utility factor for PHEVs in this report comes from the Society of Automotive Engineers (SAE) J2841 standard (SAE, 2010), specifically the multiday individual utility factor (MDIUF).

BEVs do not have a utility factor, as $100 \%$ of their driving is all-electric. BEVs have been found to generally drive less than PHEVs and ICE vehicles, though the majority of vehicles studied have all-electric ranges less than 150 miles (CARB, 2017a; CARB, 2017b; Carlson, 2015; Nicholas et al., 2017; Plötz et al., 2017; Smart and Salisbury, 2015). BEVs with longer ranges (e.g. Tesla Model S) have been found to drive comparable annual miles to PHEV and ICE vehicles. Some studies have even found BEVs with increased mileage (CARB, 2017a;

Figenbaum and Kolbenstvedt, 2016). To account for this behavior, this analysis uses the square of the utility factor for PHEVs as the effective utility factor for BEV. ${ }^{1}$ The utility factor for PHEVs and effective utility factor for BEVs are shown in Figure 3.

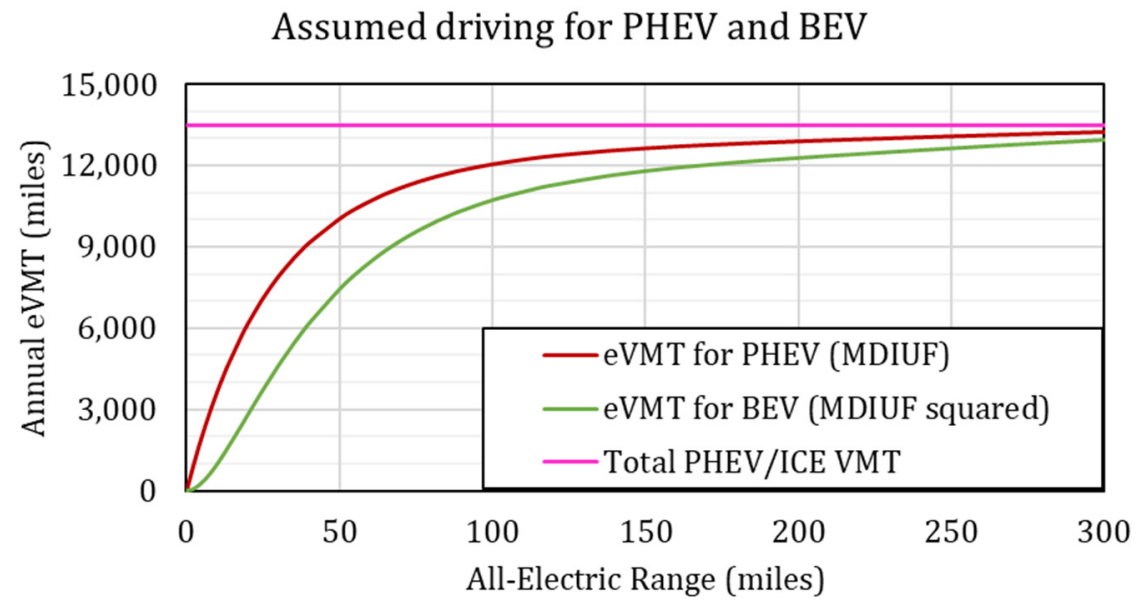

\section{FIGURE 3 Annual electric vehicle miles traveled by PEV type and range}

1 Multiple different functions were compared against data from the above references and from the 2017 NHTS. Squaring the MDIUF utility factor for PHEV yields a better least-squared fit of annual VMT for BEV than any linear scaling factor of the MDIUF, matching the real-world data better for long-range BEVs. However the variance in driving behavior is large, and there are gaps in the available data. In particular, there is a paucity of data from BEVs with all-electric range less than 60 miles or between 100 and 200 miles, which makes the predictive power of this effective utility factor uncertain. 
Given the total number of monthly PEV sales as well as the all-electric range and the effective utility factor for each vehicle, the total mileage driven in all-electric mode across the entire national light duty vehicle (LDV) fleet can be estimated. Figure 4 shows the total eVMT by year in the United States. Through 2018, more than 25 billion miles have been driven powered by electricity. In 2018, 8.6 billion miles on the road were driven by light duty electric vehicles using electric power; approximately $62 \%$ of this was driven by BEVs. The average BEV in 2018 drove 11,600 miles, while the average PHEV drove 7,300 eVMT.

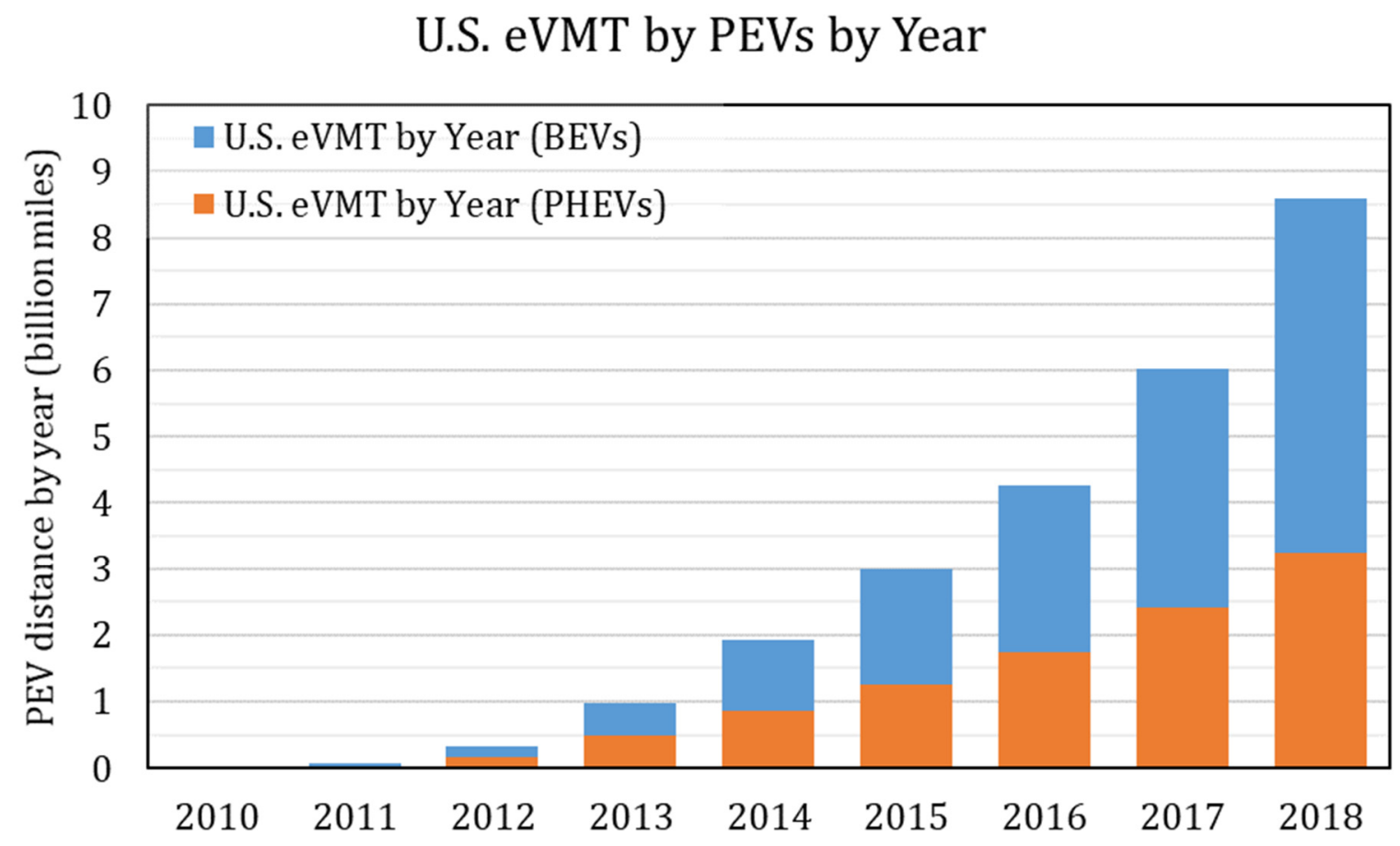

FIGURE 4 Electric vehicle miles traveled by LDVs by year

\subsection{ELECTRICITY CONSUMPTION BY PEVS}

Combining eVMT with knowledge of vehicle electricity efficiency allows us to determine the total electricity consumption by PEVs in the United States, shown in Figure 5. To find the total electricity consumption, the estimated eVMT in each month is multiplied by the electricity consumption per mile for each vehicle model. Through 2018, a total of 8.4 terawatthours of electricity have been consumed by PEVs. In 2018, the total electricity use for LDVs on the road was 2.8 terawatt-hours. In 2018, the average PHEV consumed 2,500 kilowatt-hours $(\mathrm{kWh})$ of electricity, and the average BEV consumed 3,700 kWh of electricity. This is an increase over 2017 because the average on-road BEV has a longer range in 2018, leading to higher eVMT and higher electricity consumption, even though the average efficiency also improved (see Section 3.2). 


\section{Electricity Consumption by PEVs by Year}

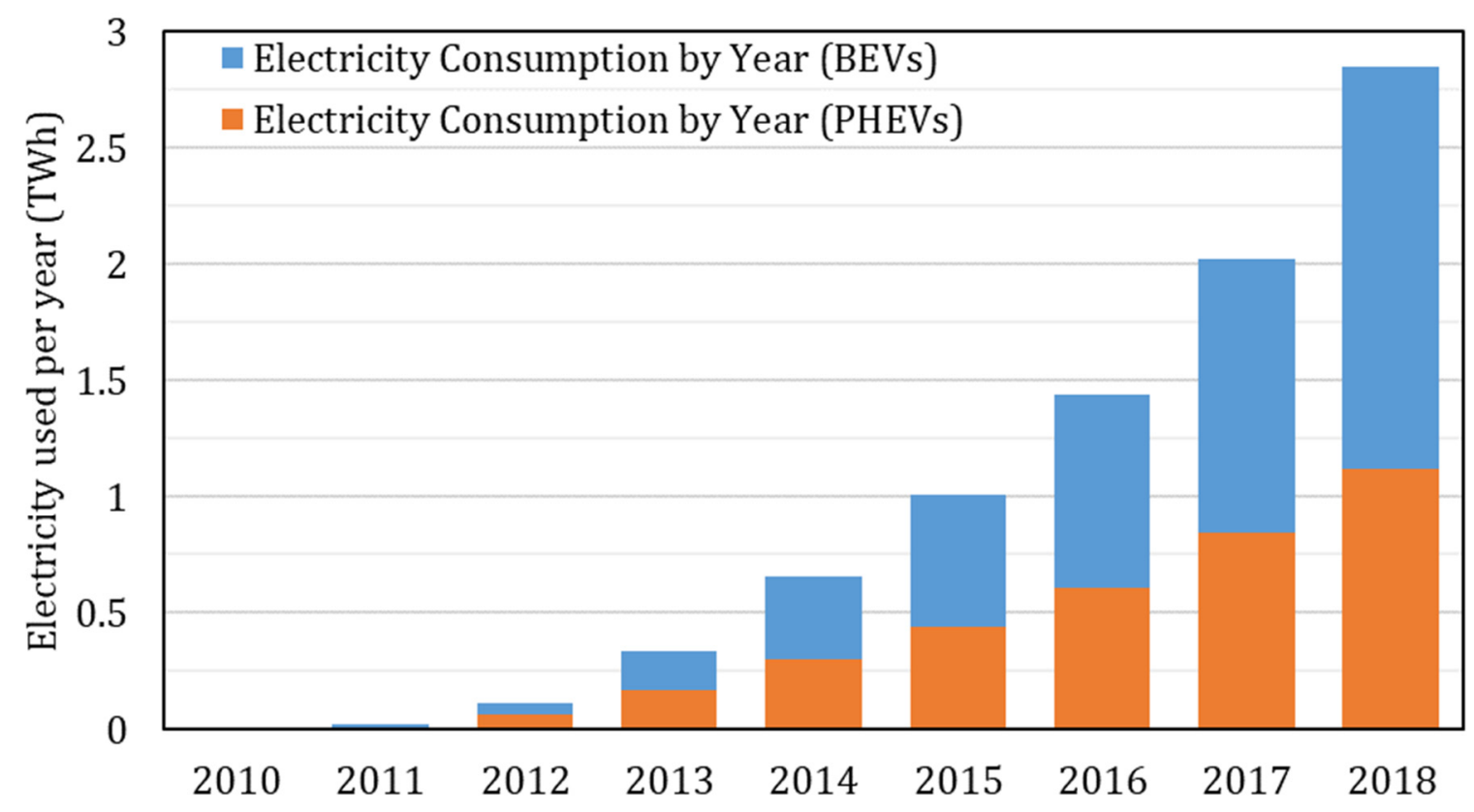

FIGURE 5 Electricity consumption by PEVs by year

\subsection{GASOLINE CONSUMPTION REDUCTION}

Use of electricity by PEVs displaces gasoline that would otherwise be used by an ICE vehicle. ${ }^{2}$ To estimate this reduction in gasoline consumption, we need to make assumptions about how each mile would have otherwise been traveled. For each PEV, we select a comparable ICE in the same size class and model year in order to calculate the gasoline consumption offset by using electricity. ${ }^{3}$ For example, a compact PEV offsets the fuel consumption of a compact ICE vehicle, rather than comparing with a fleet-wide average. Given the tendency for early adopters of electric vehicles to be interested in fuel economy and environmental benefits, the comparable gasoline ICE vehicle was assumed to be more fuel efficient than average, specifically, the 75th percentile of models available in that year in that size class. ${ }^{4}$ Section 4 examines the impact of varying the fuel economy of this reference vehicles.

The total gasoline displacement by year is graphed in Figure 6. In 2018, 320 million gallons of gasoline were offset by PEVs, with $64 \%$ of this total offset by BEVs. In 2018, the

2 This analysis only counts gasoline usage that is offset when the car is operating in electric mode. For PHEVs operating in charge-sustaining mode (i.e., using only gasoline), the hybrid engines are also generally more efficient than the average ICE vehicle, but this reduction in gasoline is not calculated here.

3 For each model year and each size class, vehicle fuel efficiencies were gathered from the FuelEconomy.gov database (DOE and EPA, 2019).

4 Since the 'Two seater' classification is largely high-performance sports cars, the Smart Fortwo Electric Drive was compared directly with the ICE version of the same vehicle instead of the remainder of the vehicles in that size class. 
average BEV offset 450 gallons of gasoline, and the average PHEV offset 260 gallons. Cumulatively, through 2018, PEVs have offset over 940 million gallons of gasoline, 585 million gallons by BEVs and 363 million gallons by PHEVs.

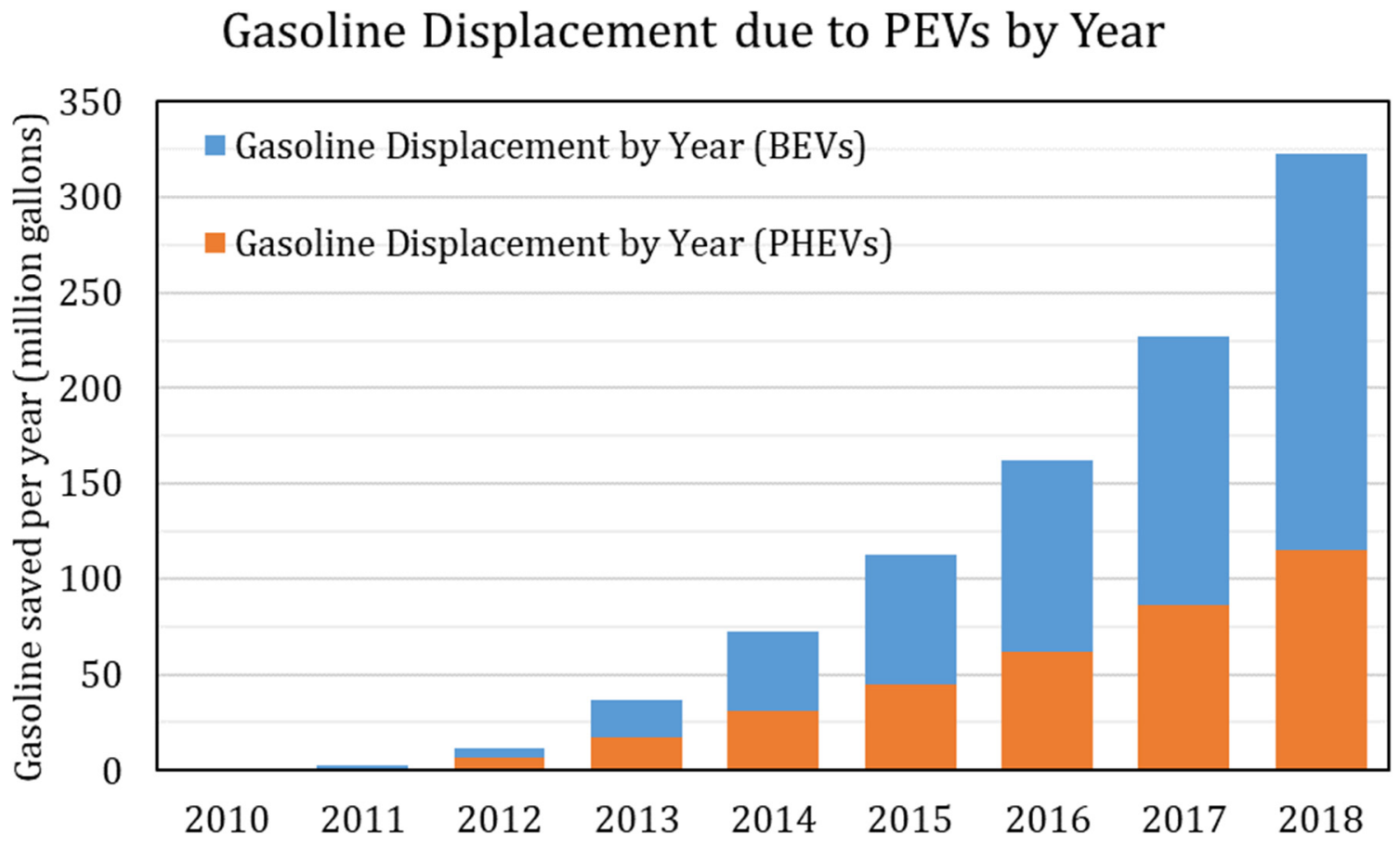

FIGURE 6 Gasoline displacement from ICE vehicles by LDV PEVs by year

\subsection{CARBON DIOXIDE EMISSIONS}

Operation of PEVs reduces emissions as well. The EPA states that combustion of each gallon of gasoline emits 8,887 grams of $\mathrm{CO}_{2}$ (EPA and DOT, 2010). ${ }^{5}$ The amount of tailpipe emissions from an ICE vehicle can be found by multiplying the miles driven by 8,887 grams $\mathrm{CO}_{2}$ / gallon of gasoline and dividing by the fuel economy (in miles per gallon, or mpg). While the carbon content of gasoline is constant, emissions from electricity production have been decreasing. According to the EPA, electricity production in the United States emitted an average of 453 grams of $\mathrm{CO}_{2}$ per kilowatt-hour in 2016 (EPA, 2018a), down 19\% from the $559 \mathrm{~g} \mathrm{CO}_{2}$ / $\mathrm{kWh}$ emitted in 2010. The emissions to drive an electric vehicle are found by multiplying the miles driven by the electricity consumption (in $\mathrm{kWh}$ per mile) by the emission rate. As an example, an ICE vehicle consuming $30 \mathrm{mpg}$ emits $300 \mathrm{~g} \mathrm{CO}_{2}$ / mile, while a BEV consuming

5 This calculation is for tailpipe emissions only; that is, it excludes upstream effects for refining and transportation of the fuel, as well as emissions from the production of the vehicles. For electric vehicles, the calculation is for the generation of the electricity for vehicle operation, again excluding vehicle manufacturing. The majority of emissions come from the operation, rather than the manufacturing, of both ICE vehicles and PEVs. A recent study found that tailpipe emissions from a midsize gasoline ICE vehicle were $68 \%$ of the total lifetime emissions, while electricity consumption for operation was responsible for $77 \%$ of the emissions from a midsize BEV (Elgowainy et al., 2016). 
$0.33 \mathrm{kWh}$ / mile in 2016 was responsible for $150 \mathrm{~g} \mathrm{CO}_{2} /$ mile. Assuming the U.S. national grid average for emissions from electricity production, and comparing each PEV with the $75^{\text {th }}$ percentile ICE vehicle for fuel economy in its size class in each year, PEVs have offset a total of 4.5 million metric tons of carbon dioxide during vehicle operation.

\subsection{NATIONAL-SCALE COMPARISONS}

PEVs are a growing share of the vehicle market and are having increasing impacts on the transportation and energy sectors. Figure 7 highlights how these impacts have changed, comparing the quantities from PEVs for total number of on-road vehicles, miles driven, electricity consumption, and gasoline reduction with corresponding total national values. For most national data, 2017 is the latest year with full data availability as of the writing of this report (February 2019), so Figure 7 uses extrapolated values of vehicle registrations, VMT, gasoline consumption, and electricity consumption to estimate through 2018. In 2017, PEVs comprised $0.30 \%$ of the 250 million light-duty vehicle registrations (FHWA, 2018b). That year, the Federal Highway Administration (FHWA) found nearly 3 trillion miles driven by light-duty vehicles in the United States (FHWA, 2018c; FHWA, 2019), for comparison, over 6 billion, or $0.21 \%$ of all LDV mileage, were powered by electricity. In 2017 , the total electricity use for LDVs on the road was 2.0 terawatt-hours. This compares with a total of 3,820 terawatt-hours (EIA, 2018), or $0.053 \%$ of the total national electricity generation. In 2017, 227 million gallons of gasoline were offset by PEVs, equivalent to $0.16 \%$ of the 138 billion gallons of gasoline used in the United States that year (EIA, 2018).

\section{PEV share of national totals}

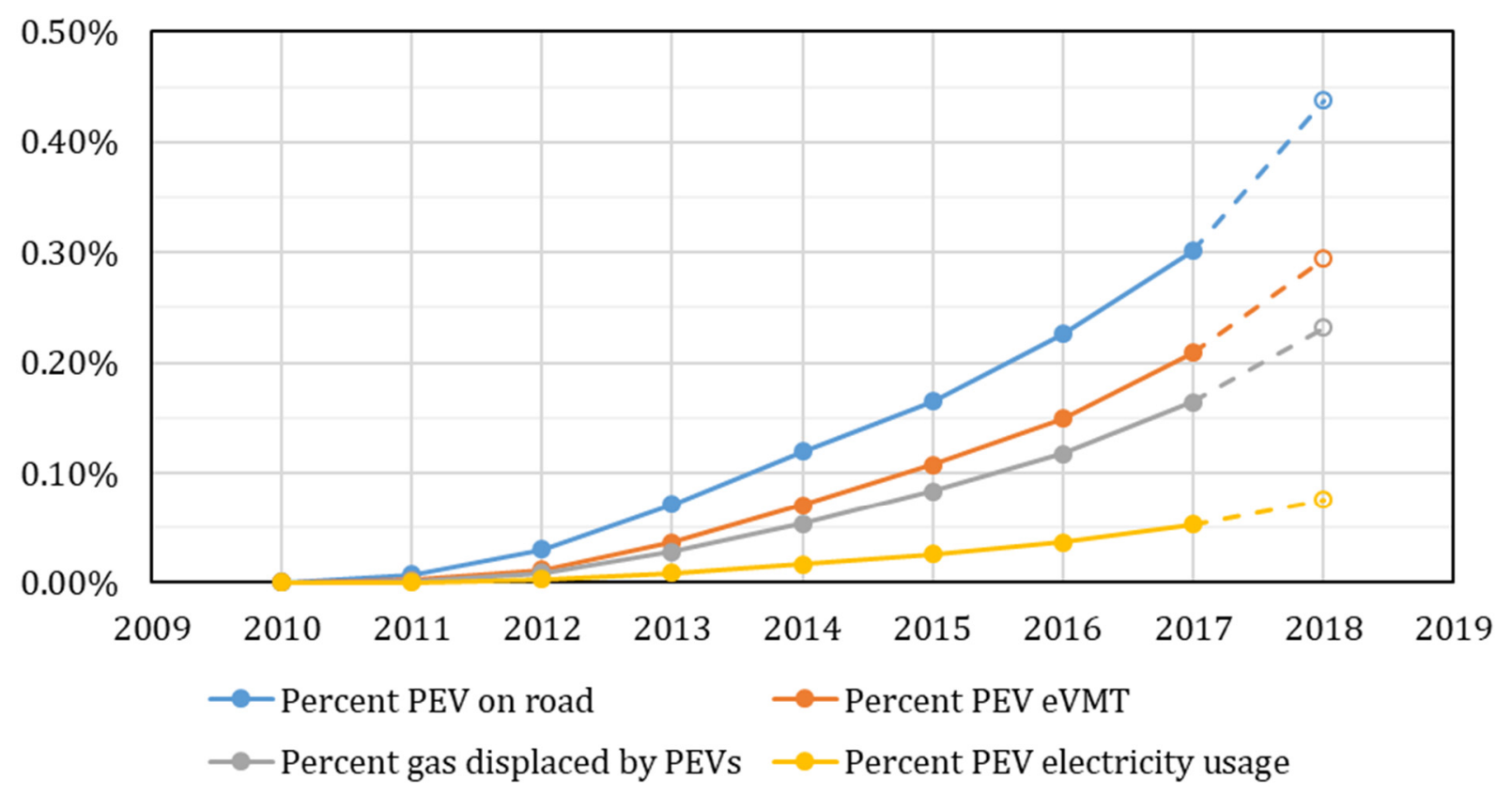

FIGURE 7 Fraction of key national metrics which are due to PEVs in the United States by year 


\section{VEHICLE CHARACTERISTICS}

In addition to the total national-scale impacts of PEVs presented in Section 2, specific trends within the PEV market can be examined, including all-electric range, energy efficiency, vehicle size, performance, battery size, and manufacturing location.

\subsection{ALL-ELECTRIC RANGE}

The average range of PEVs has increased since 2010. This is largely due to the introduction and increased consumer preference of longer-range BEVs. Figure 8 shows the average sales-weighted all-electric range for new vehicles (left side) and for all on-road vehicles (right side). PHEVs have consistently averaged between 20 and 35 miles of all-electric range while the average range of BEVs has grown from approximately 70 miles to over 200 miles. The sharp growth in all-electric range for BEVs in early 2013 is due to the introduction of the Tesla Model S, with a range of up to 265 miles, while the increase in 2018 is largely due to high sales of the Tesla Model 3 with a range of up to 310 miles.
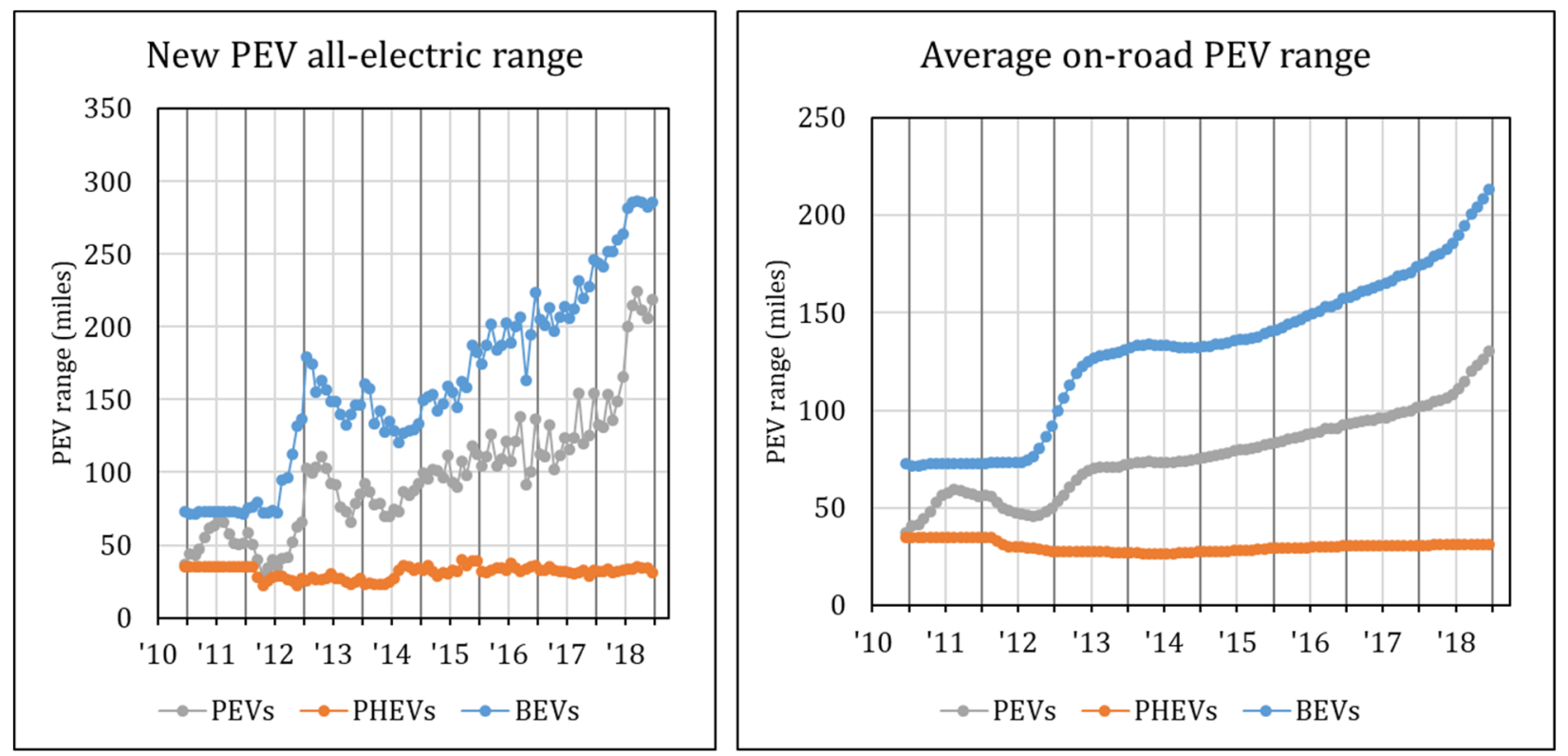

FIGURE 8 All-electric range for PEVs. Left side: new vehicles sold in each month. Right side: average on-road vehicles. 


\subsection{ENERGY EFFICIENCY}

Figure 9 shows the average (distance-weighted) energy efficiency of vehicles running on electricity for new vehicles (left) and the entire on-road fleet of PEVs (right). ${ }^{6}$ Since 2010, vehicles have become more efficient on average. Variability in the sales mix leads to relatively large changes in average electricity consumption month-to-month for newly purchased PEVs, while the average of the entire PEV fleet has had smaller monthly variability.
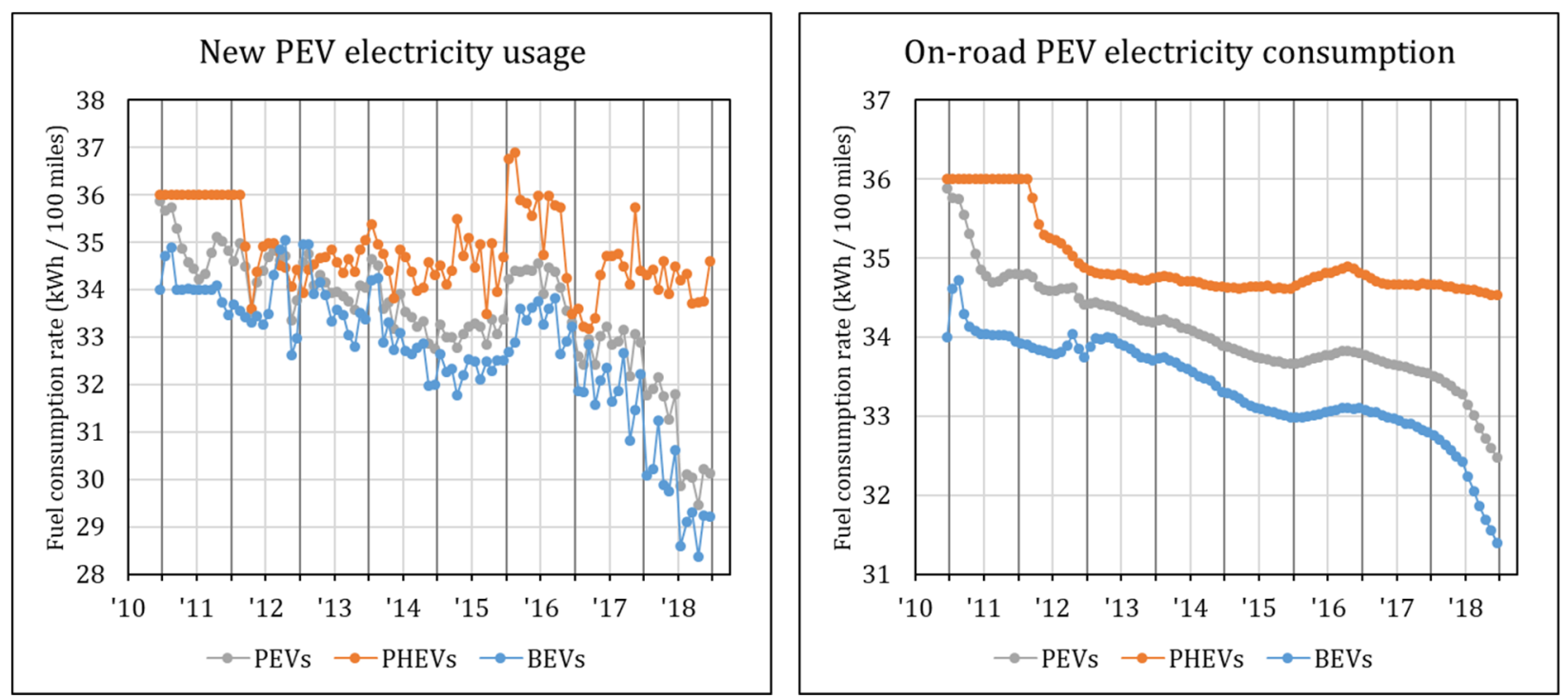

FIGURE 9 Electric efficiency for PEVs. Left side: new vehicles sold in each month. Right side: average on-road vehicles.

The average electricity consumption of the entire PEV fleet has dropped from nearly 36 $\mathrm{kWh}$ per 100 miles to under $33 \mathrm{kWh}$ per 100 miles. BEVs sold in the United States have generally been more efficient than PHEVs. As of December 2018, the average on-road PHEV consumed $34.5 \mathrm{kWh}$ per 100 miles driven in charge-depleting (all-electric) mode, while the average on-road BEV consumed $31.4 \mathrm{kWh}$ per 100 miles. In terms of miles per gallon of gasoline equivalent (MPGe), where 33.7 kilowatt-hours of electricity is equivalent to one gallon of gasoline (EPA, 2011), the average PEV fuel economy has increased from 94 MPGe to 104 MPGe. As with the all-electric range, the rapid changes in 2018 were due to high sales of the efficient Tesla Model 3, which averages approximately $27 \mathrm{kWh}$ per 100 miles. The most efficient vehicles in the FuelEconomy.gov database are the Hyundai Ioniq BEV and Toyota Prius Prime PHEV, each consuming $25 \mathrm{kWh} / 100$ miles when operating on electricity (DOE and EPA, 2019).

${ }^{6}$ A distance-weighted average (rather than a sales-weighted average) gives a proper comparison of electricity consumption of the entire PEV fleet. For BEVs, the sales-weighted and distance-weighted fuel economies have been very similar each month. Since shorter-range PHEVs (around 10-15 mile range) have worse fuel efficiency than longer-range PHEVs in the FuelEconomy.gov database, and do not drive as many miles as those with longer ranges, the distance-weighted average is more efficient than the sales-weighted average for PHEVs. 


\subsection{SIZE CLASS AND VEHICLE WEIGHT}

Figure 10 shows PEVs sorted by size class. The most common vehicle each year for PEV sales has been a midsize car, which includes the Nissan Leaf, Toyota Prius Prime, and Tesla Model 3. This is followed by compact cars, which are more prominent for PHEVs, such as the Chevrolet Volt, and by large cars, such as the Tesla Model S BEVs. Sales for sport utility vehicle (SUV) PEVs are growing, with standard four-wheel drive SUV (including the Tesla Model X) being the third best-selling size class of 2018 .

On-road PEVs by size class

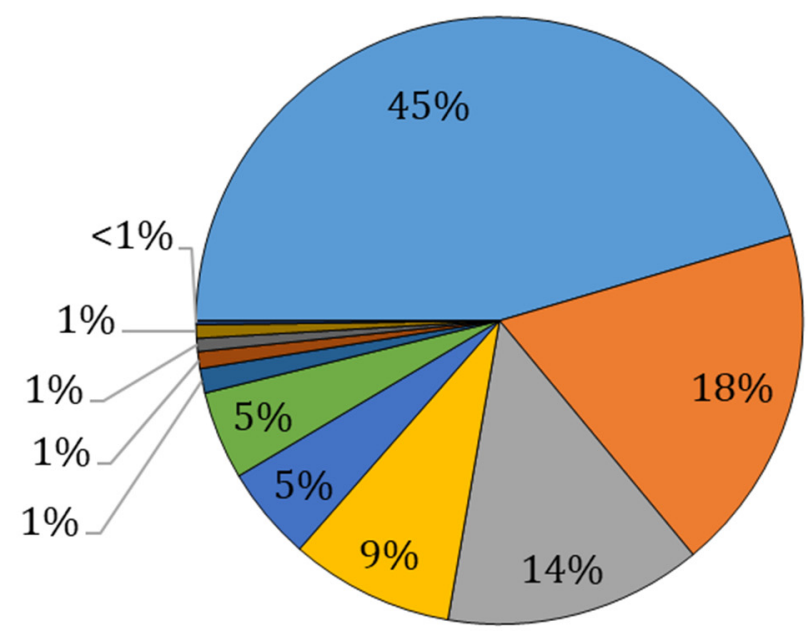

$\square$ Midsize Cars
$\square$ Compact Cars
$\square$ Large Cars
$\square$ Standard Sport Utility Vehicle 4WD
$\square$ Subcompact Cars
$\square$ Small Station Wagons
$\square$ Minicompact Cars
$\square$ Minivan - 2WD
$\square$ Two Seaters
$\square$ Small Sport Utility Vehicle 4WD
$\square$ Small Sport Utility Vehicle 2WD

FIGURE 10 Cumulative sales of PEVs by EPA size class

The EPA splits LDVs into five different vehicle types: cars, car SUVs, truck SUVs, minivans/vans, and pickup trucks (EPA, 2019). Vehicles defined as cars by the EPA make up $89 \%$ of total PEV sales, and $10 \%$ of PEV sales have been SUVs. In 2018, car SUVs comprised $11 \%$ of BEV sales. Truck SUVs were $12 \%$ of PHEV sales and minivans/vans were more than $5 \%$ of PHEV sales.

The EPA collects data on vehicle weights as part of the fuel economy testing process. The EPA maintains a publicly accessible database of the equivalent test weight of each vehicle, classified into 125- and 250-pound groups (EPA, 2018b). ${ }^{7}$ The sales-weighted average of these equivalent test weights for PEVs has increased from 3,800 pounds in 2011 to 4,400 pounds in 2018. Over that timeframe, the sales-weighted average equivalent test weight has increased from 3,700 pounds to 4,500 pounds for BEVs, and from 4,000 to 4,200 pounds for PHEVs. This weight increase is due to increased battery capacity in BEVs and due to larger average size classes for both BEVs and PHEVs.

\footnotetext{
7 Because of this grouping of vehicles in the EPA database, the equivalent test weight group for each vehicle is
} similar to, but not exactly the same as, its test weight basis. 


\subsection{VEHICLE PERFORMANCE}

Performance of electric vehicles has on average increased since 2010, as measured by electric motor power (in kilowatts) and by the acceleration time from 0 to 60 miles per hour (mph). Figure 11 shows the average total electric motor size and acceleration for PEVs sold in each year. ${ }^{8}$ For each of these metrics, much of the increase in vehicle performance for BEVs has been due to Tesla. The (sales-weighted) average motor size for a Tesla BEV has increased to over $250 \mathrm{~kW}$ and to $130 \mathrm{~kW}$ for BEVs sold by other automakers. For the Tesla vehicles, the total motor power is increased by having separate motors for front and rear wheels for their all-wheel drive variants. ${ }^{9}$ Since 2014, the average electric motor size for PHEV has remained steady at around $90 \mathrm{~kW}$; PHEVs have an additional gasoline-powered engine for propulsion, and therefore have less need for a larger electric motor.
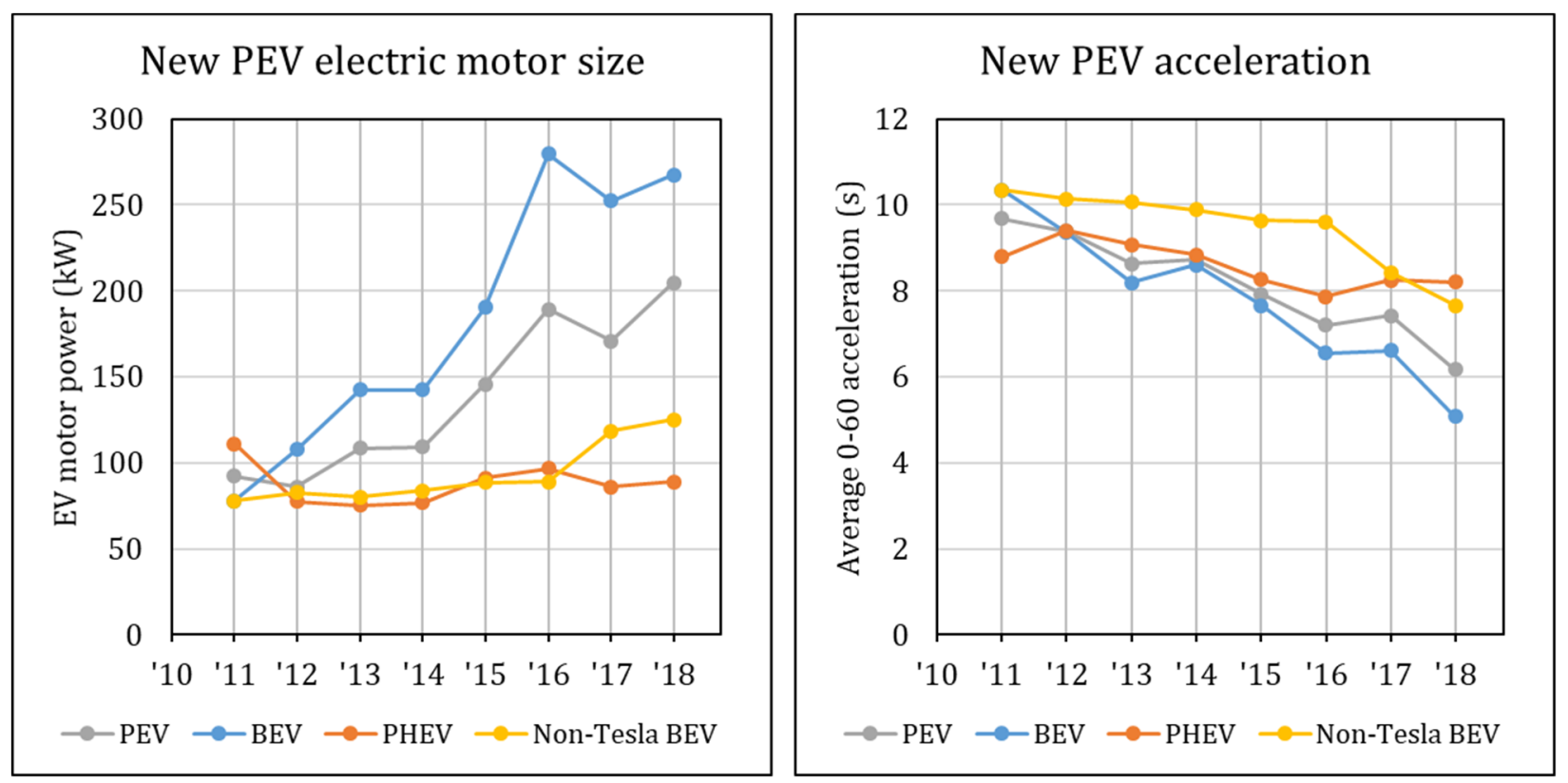

FIGURE 11 Average performance indicators for PEVs sold in each month

As PEV electric motors have become more powerful, vehicle acceleration has improved. The average time for a PEV to reach $60 \mathrm{mph}$ is approximately 6 seconds. As with the electric motor power, much of the change since 2011 comes from Tesla vehicles. The fastest available PEV is the Tesla Model S P100D, which can reach $60 \mathrm{mph}$ in 2.5 seconds. The average $0-60$ mph time for PHEVs has been consistently between 8 and 9 seconds since 2013. Through 2016, the sales-weighted average $0-60 \mathrm{mph}$ time for a non-Tesla BEV was 10 seconds, though this has

8 For performance and acceleration, all trim levels are combined into a single data point for each model. Therefore, there may be monthly variation in sales trends of individual models for that are not captured in these figures.

9 For Tesla vehicles, the typical trim level of each model is an estimate of the sales-weighted average across all of the available trims, as Tesla does not separate out the different trim levels in their quarterly sales reports. For lack of nationwide U.S. sales data, the fraction for each trim is estimated based on public registration data from Norway, the United Kingdom, Germany, the Netherlands, and New York State, which combine for about $20 \%$ of the global market (Edvardsen, 2019; GOV.UK, 2019; KBA, 2019; NYS DMV, 2019; RDW, 2019). 
dropped to less than 8 seconds by the end of 2018, and new BEVs are now quicker on average than PHEVs. This overall improvement in average PEV acceleration rates has multiple causes, including increased availability of models with faster acceleration and some specific models becoming quicker as technology improves.

\subsection{VEHICLE MANUFACTURING AND ASSEMBLY}

Most electric vehicles that have been sold in the United States were assembled in the United States, as shown in Figure 12. Over five-sixths of BEVs and nearly half of PHEVs have been assembled in the United States. Most of the remaining PEVs sold in the United States were assembled in Germany, Japan, and Mexico. A higher fraction of PEVs have been assembled domestically than ICE vehicles.

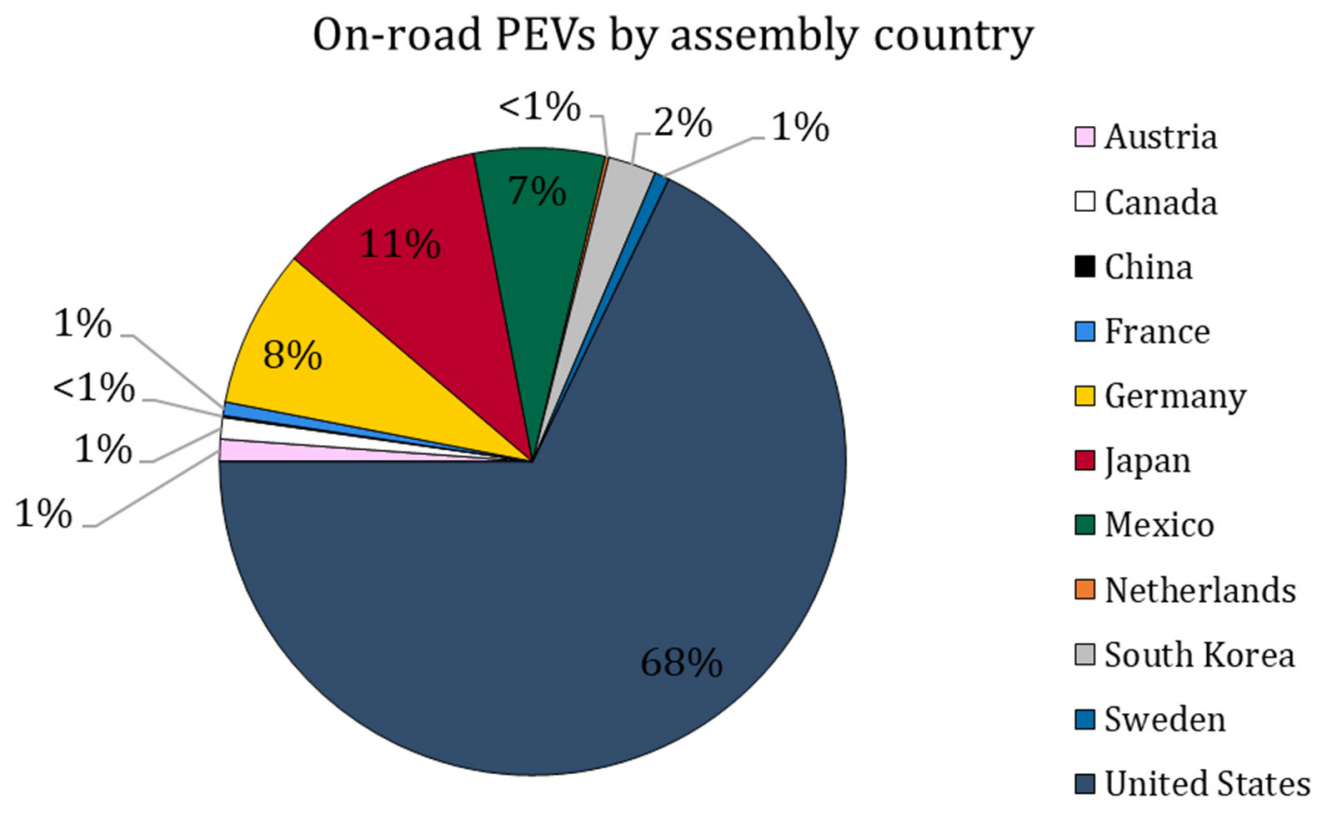

FIGURE 12 Assembly location for PEVs sold in the United States through 2018

Figure 13 shows how assembly location and vehicle content has changed over time. In 2011 and early 2012, most PEVs sold in the United States were assembled in Japan, led by the Nissan Leaf and Toyota Prius Plug-in. By the end of 2012, the Nissan Leaf was being produced in Tennessee and additional models (from Ford and Tesla) were being produced in the United States. From 2013 to 2017, about one-third of PEVs were assembled in foreign countries. In 2017, 63\% of PEV were assembled in the United States, including $87 \%$ of BEV; for comparison, $52 \%$ of non-PEV vehicles were assembled in the United States, based on import data from the Department of Commerce (ITA, 2018). In 2018, largely due to the strong sales growth of the Tesla Model 3,75\% of PEVs were assembled in the United States. 

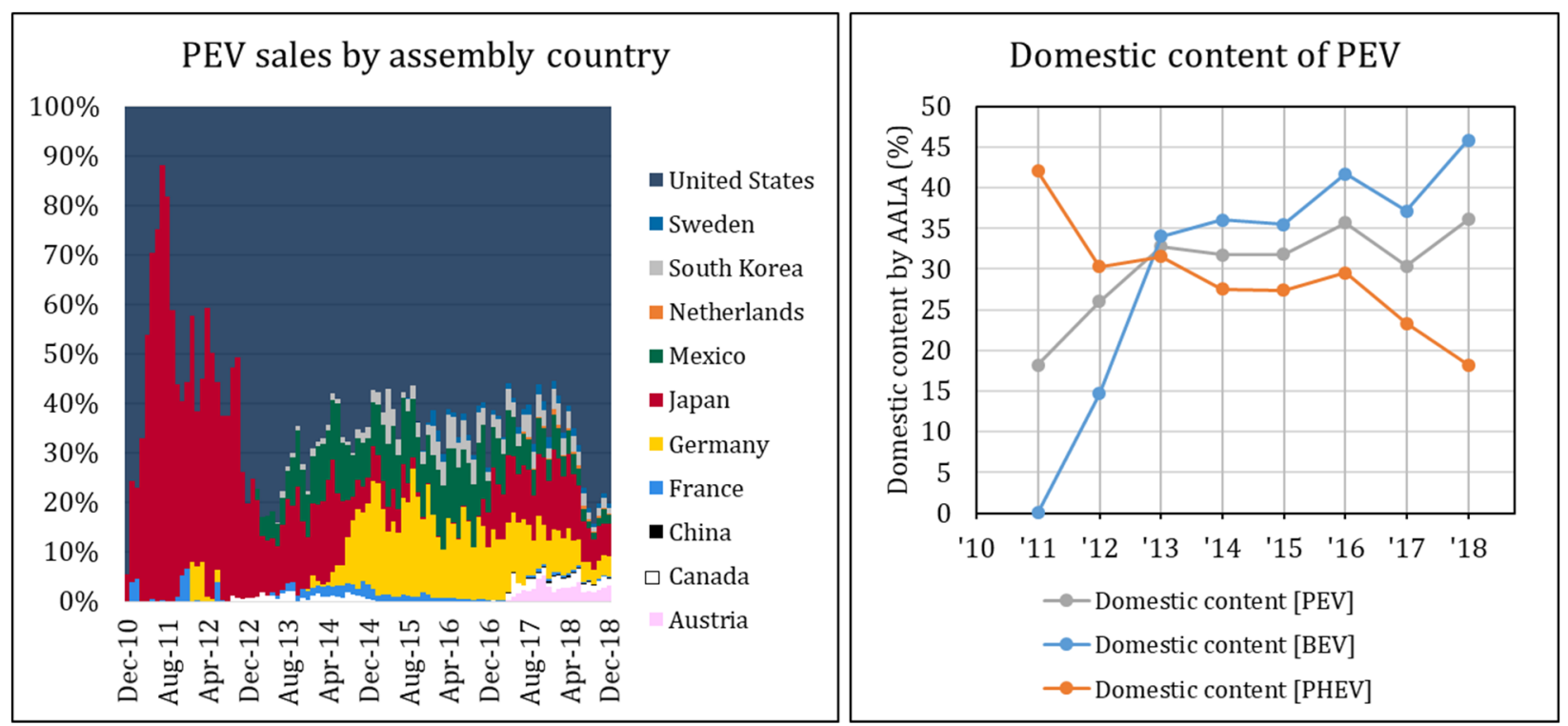

FIGURE 13 Assembly location by month and annual sales-weighted AALA domestic content for PEVs sold in the United States from 2010 to 2018

The fraction of vehicle components that are produced domestically (here defined as both United States and Canada) come from the AALA reports that are compiled by NHTSA for each vehicle model (NHTSA, 2018). Figure 13 shows the sales-weighted average of these AALA values for PEVs sold in the United States. This figure shows that the total amount of domestically sourced materials in electric vehicles has grown since 2011, with strong growth from 2011 to 2013 for BEVs. In 2013, about one-third of materials in both BEVs and PHEVs were domestically sourced. ${ }^{10}$ Since then, the fraction of domestic content in PHEVs has declined, largely due to an increasing selection of models produced throughout the world. The fraction of domestic content in BEVs has increased, due to the growth in sales by Tesla and the assembly of Nissan Leafs in the United States.

A similar quantification of U.S. manufacturing is put together by the Kogod School of Business at American University. In their 'Made in America' index they compile their estimate of domestic production which includes investment and different vehicle components (Dubois, 2018). ${ }^{11}$ In the most recent 2018 MIA estimate, the Chevrolet Volt ranked as the \#2 most domestically sourced vehicle while the Tesla Model S was \#8. Similarly, the Cars.com 2018 American-Made Index ranks the Chevrolet Volt as \#5 (Mays, 2018).

${ }^{10}$ AALA reports do not account for changes in manufacturing process throughout the year. For example, in early 2013 the Nissan Leaf was largely imported. By the end of the year, the Smyrna plant in Tennessee was assembling Nissan Leafs with a larger fraction of domestically sourced parts, but that does not show up in the AALA report for MY2013 vehicles (Voelker, 2013).

${ }^{11}$ A large portion of the Kogod Made in America Index is informed by NHTSA's AALA estimates, so they are not entirely independent of each other. 


\subsection{VEHICLE PRICE}

Figure 14 shows the sales-weighted average MSRP for PEVs for 2010-2018. ${ }^{12}$ The costs shown here are the base trim MSRP. ${ }^{13}$ This is not necessarily the cost a consumer will pay for the vehicle (and does not include state or federal tax incentives) but is a price that can be referenced as a benchmark for each vehicle. For comparison, the average transaction price for light-duty vehicles, as per the Bureau of Economic Analysis, is shown (BEA, 2018). The average cost of BEVs has gone up somewhat since 2010, while the average cost of PHEVs has declined slightly since then. For individual vehicle models, the prices have largely dropped or stayed steady. However, consumers have opted for more expensive models, increasing the average cost of PEVs.

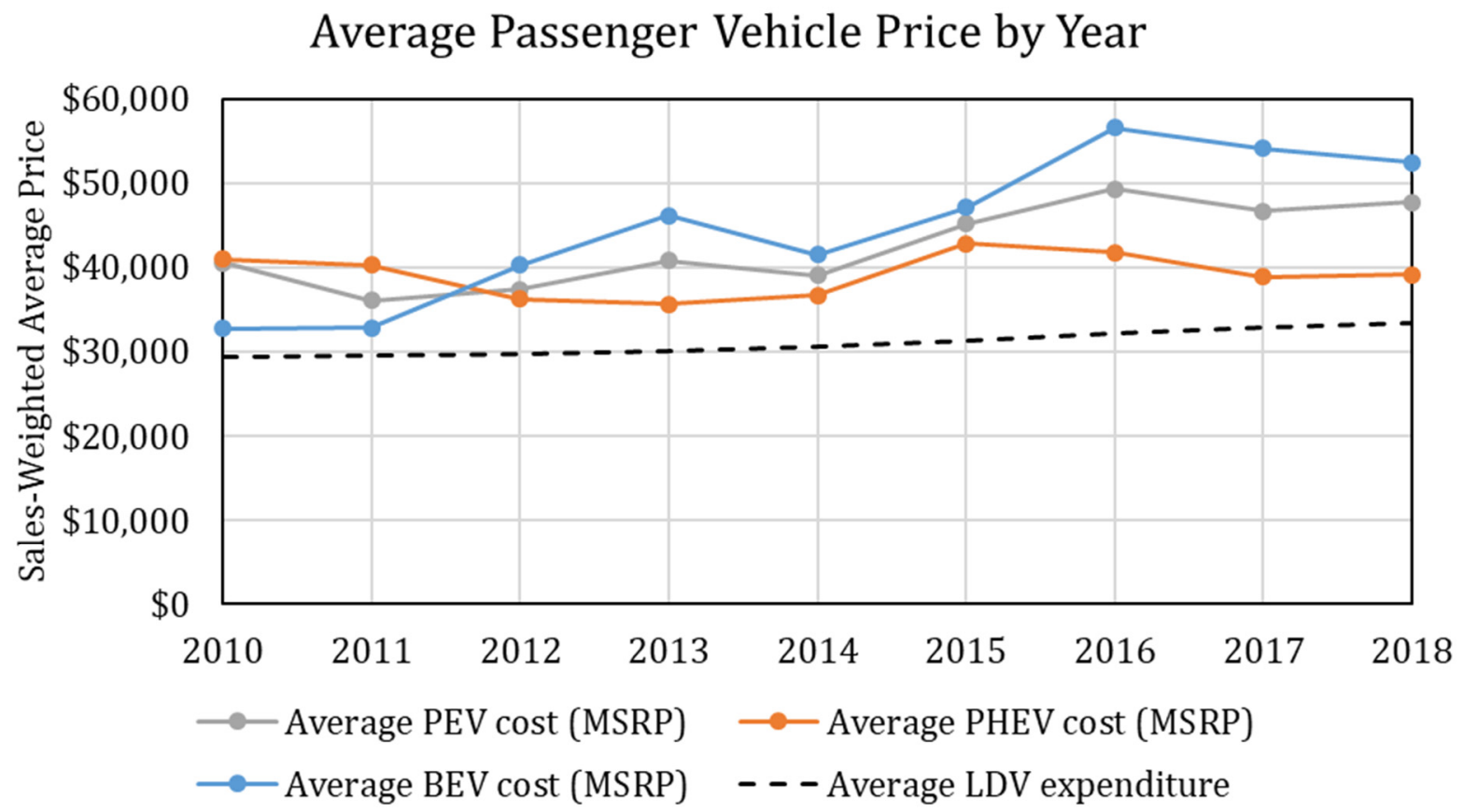

FIGURE 14 Average MSRP for PEV sold from 2010 to 2018; average transaction price for light-duty vehicles included for comparison

Purchases of PEVs are eligible for a federal tax credit of up to $\$ 7,500$ (IRS, 2009). This tax credit exists until the automaker sells its $200,000^{\text {th }} \mathrm{PEV}$, at which point the credit is phased out over the next year. The Internal Revenue Service is the final arbiter on tax credit eligibility, but Tesla announced in July 2018 that they reached the threshold (Tesla, 2018), and General Motors reached the threshold in the final quarter of 2018 (Chevrolet, 2019).

12 All values here are nominal dollars, not inflation-adjusted. From 2011 to 2017, the Consumer Price Index (CPI) increased by $1.4 \%$ per year, and so a cost in 2011 would need to be increased by $9 \%$ to be adjusted for inflation to $2017 \$$.

13 There are many vehicle models which have a large suite of optional technologies and features which can bring the cost higher than the base level. 


\subsection{BATTERY CAPACITY AND CATHODE CHEMISTRY}

Since 2010, the commercially available PEVs in the United States have used lithium-ion batteries for energy storage. These batteries are comparatively lightweight, and batteries with capacities of up to $100 \mathrm{kWh}$ have been included in PEVs. The core components of lithium-ion batteries are the anode and the cathode. Most lithium-ion batteries have a graphite anode, though a few vehicles (e.g. Mitsubishi i-MiEV, Honda Fit) have used lithium titanate (LTO, $\mathrm{Li}_{4} \mathrm{Ti}_{5} \mathrm{O}_{12}$ ) instead (Blomgren, 2017). The cathode is the most expensive component of the lithium-ion battery (Pillot and Sanders, 2017), and there are numerous competing chemistries for the cathode.

The most common cathode chemistries for lithium ion batteries for automotive uses are $\mathrm{LiNi}_{0.8} \mathrm{Co}_{0.15} \mathrm{Al}_{0.05} \mathrm{O}_{2}$ (NCA), $\mathrm{Li}\left[\mathrm{Ni}_{1-\mathrm{x}-\mathrm{y}} \mathrm{Mn}_{\mathrm{x}} \mathrm{Co}_{\mathrm{y}}\right] \mathrm{O}_{2}$ (NMC), $\mathrm{LiMn}_{2} \mathrm{O}_{4}$ (LMO), and $\mathrm{LiFePO}_{4}$ (LFP). For a detailed description of the relative merits of each of these chemistries, see e.g. Berman et al. (2018), Andre et al. (2015) and Schmuch et al. (2018). These four cathode chemistries are the most common worldwide (EV Volumes, 2017b; Azevedo et al., 2018). As of 2017, NMC and NCA each made up about one-third of the total installed capacity worldwide, and LFP and LMO comprised nearly all of the rest. There are trends toward higher nickel content (and lower cobalt content) in NMC batteries to reduce costs (Berman et al., 2018). ${ }^{14}$ It is generally not reported what stoichiometry battery cathodes use in each PEV, though NMC-111 was the most common in 2010, and NMC-622 and NMC-811 are beginning to be produced (Pillot and Sanders, 2017).

Figure 15 shows the primary cathode material for electric vehicles sold in the United States over time. ${ }^{15}$ The left figure is a function of vehicle sales, and the right figure shows the total battery capacity (in MWh) for each cathode chemistry. Figure 16 shows that NMC and NCA are the dominant cathode chemistries in the United States in 2018. Further, while NCA and NMC were used as the battery cathode in a similar number of vehicles, the total capacity was four times higher for NCA, indicating that NCA has been used in much larger packs, on average.

${ }^{14}$ The stoichiometric ratio of nickel, manganese, and cobalt can be varied in NMC batteries. NMC batteries are often labeled as NMC-xyz, where $\mathrm{x}, \mathrm{y}$, and $\mathrm{z}$ are the ratios between $\mathrm{Ni}, \mathrm{Mn}$, and Co.

${ }^{15}$ It is common for cathode chemistries to be mixed. In particular, LMO and NMC are often mixed in batteries - for ease of representation, the present analysis shows only the primary cathode chemistry. 

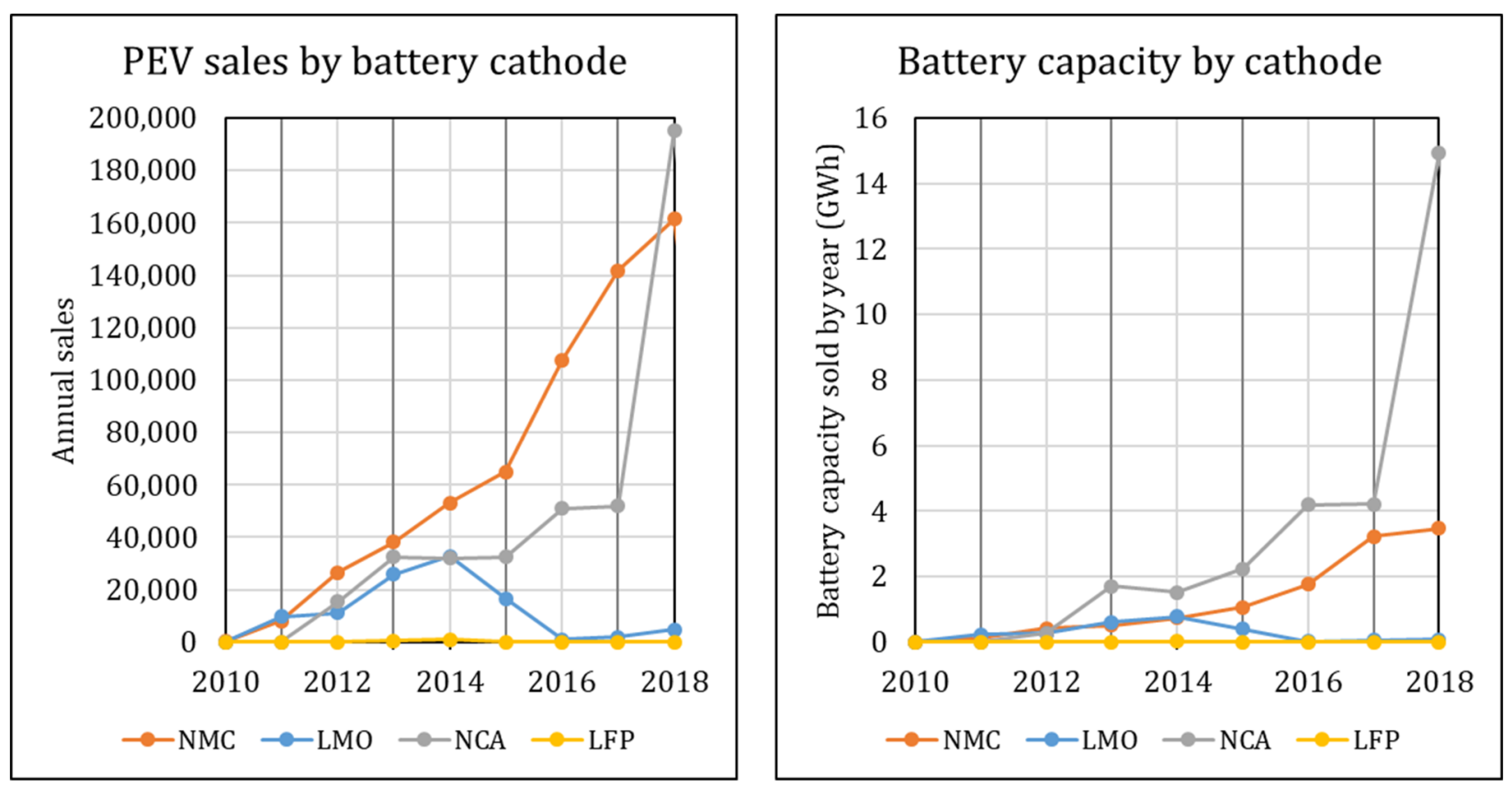

FIGURE 15 Battery capacity added each year for LDV PEVs in the United States

The aggregate battery capacity in PEVs sold in the United States is over 42 gigawatthours (GWh) through 2018. Figure 15 shows the new batteries added to the road each year from 2010 through 2018; new battery capacity reached $18.5 \mathrm{GWh}$ in 2018 . Of this, nearly $15 \mathrm{GWh}$ used NCA cathodes, and over 3 GWh used NMC cathodes. 94\% of PHEVs sold in 2018 used lithium-ion batteries with NMC cathodes. More than two-thirds of the total battery capacity has used NCA cathodes, and most of these NCA batteries have been installed in Tesla vehicles. 


\section{SENSITIVITY ANALYSES}

This section explores variations in the input data and assumptions to examine the robustness of the results. This was done in detail in the previous iteration of this report (Gohlke and Zhou, 2018) and many results here reference that work. The largest variations in the results come from assumptions about traveler behavior and ICE vehicle replacement. Scrappage and end-of-life are also worth describing here.

\subsection{TRAVELER BEHAVIOR}

The baseline VMT in this study was fixed at 13,500 miles/year. As noted above in Section 2, this corresponds to the average distance driven by a comparable ICE vehicle (Lu, 2006). Tuning this parameter affects all vehicles equally and acts as a simple linear scaling factor for eVMT, electricity consumption, gasoline displacement, and $\mathrm{CO}_{2}$ emissions.

The fraction of PHEV VMT driven on electricity is determined by a utility factor, and BEVs have an effective utility factor in this report, which can be thought of as representing driver reluctance to fully discharge the battery or use BEVs for long-distance trips. These behavioral factors are strongly dependent on the vehicle make and model, and average values are used in this report. The previous iteration of this report (Gohlke and Zhou, 2018) explored these utility factors in depth. In that report, using the SAE Fleet Utility Factor resulted in 6\% lower eVMT, while the utility factors from the World harmonized Light vehicles Test Procedure increased eVMT by up to $16 \%$.

The previous report used a simple $15 \%$ reduction in eVMT for BEV, however, vehicles with longer range appear to have a lower penalty. Therefore, this report uses the squared MDIUF utility factor to find total VMT for BEV. To compare with the methodology of the previous report, using a $15 \%$ reduction yields a cumulative national eVMT estimate which is $4 \%$ lower than in this report.

\subsection{VEHICLE SALES AND STOCK}

Default sales estimates in this analysis come from Argonne National Laboratory (ANL, 2019), HybridCars (Cobb, 2018), and InsideEVs (Inside EVs, 2019). Several manufacturers, most notably Tesla and General Motors, do not report U.S. sales monthly for each model, so there are variations between these sales estimates, though the results are similar for all sales estimates considered.

Tesla reports sales quarterly and globally and aggregates across all trim levels for each model. This results in uncertainty for sales estimates and about which vehicles were sold. For example, for MY2016, 13 different trim levels were available for the Model S with battery sizes ranges from $60 \mathrm{kWh}$ to $100 \mathrm{kWh}$, efficiencies ranging from $0.32 \mathrm{kWh} / \mathrm{mile}$ to $0.38 \mathrm{kWh} / \mathrm{mile}$, and all-electric ranges from 210 miles to 315 miles. In this report, the baseline weighting factors 
of sales of each trim level for each model are derived from public registration data from Norway, the United Kingdom, Germany, the Netherlands, and New York State (Edvardsen, 2019; GOV.UK, 2019; KBA, 2019; NYS DMV, 2019; RDW, 2019). Because the effective utility factor for the Tesla vehicles is high for every model, the impact of the exact variation in vehicle attributes is small for the macroeconomic aggregated indicators (i.e., VMT, electricity consumption, gasoline displacement, and carbon emissions). For example, for MY2016 Tesla Model $\mathrm{S}$, the longest driving range is $50 \%$ greater than the lowest driving range, but its effective utility factor is only 5\% higher (as described in Figure 3). Uncertainty in the vehicle mix does have a major impact on battery capacity and performance measures. Cumulative battery production ranges between $35.1 \mathrm{GWh}$ and $46.0 \mathrm{GWh}$ through December 2018 depending on if all Tesla vehicles have the smallest or largest batteries available, respectively. Since 2015, each Tesla model has offered a performance version, which has acceleration that can be more than twice as quick as the base version (e.g., 0-60 mph times ranging from $2.5-5.5$ seconds for the 2017 Model S).

Scrappage effects are currently small. Using National Highway Traffic Safety Administration's (NHTSA) 2006 report as the basis of scrappage rates, which uses historic data from ICE vehicles (Lu, 2006), less than 3\% of PEVs sold have been taken off the road, as of December 2018. ${ }^{16}$ This fraction is small because of the average age of PEVs. The average age of on-road PEVs is only 29 months, due to their recent introduction into the market and the rapid growth in sales. If PEV sales remain steady at 2018 levels (30,000 sales per month), scrappage will not reach $10 \%$ until after 2025 , and the overall fraction of scrapped vehicles will be lower still if PEV sales increase (due to a younger average PEV fleet).

A potentially larger impact comes from reduction of vehicle use as the vehicle ages. NHTSA has a vehicle mileage schedule for estimated travel by age of vehicle, based on historical ICE data ( $\mathrm{Lu}, 2006$ ). Translating this vehicle mileage schedule (for cars) to the PEV sales since 2010 yields a 4\% reduction in VMT from 2010 through 2018. It is unknown if this methodology translates to eVMT driven by PEVs. ${ }^{17}$ Using data from the 2017 NHTS, BEV exhibit no clear reduction in mileage for vehicles dating back to 2011, while PHEV show a decrease in mileage using NHTS's best estimate, but an increase in mileage when relying on self-reported mileage. In either case, the sample size for each of these vehicles is small.

Due to the effects of scrappage and vehicle travel effects, the impacts of PEV usage on gasoline displacement and electricity use may be overestimated. Combining the reduction in onroad vehicles with the reduction in mileage for older vehicles (both assuming equivalent

\footnotetext{
${ }^{16}$ For the first several years of a vehicle's life, the scrappage rate from NHTSA is approximately $0.12 \%$ per month. The EPA Technical Assessment Report (EPA, 2016) assumes an even slower scrappage rate.

17 There are logical reasons that the eVMT could either be reduced or stay the same. For BEVs, a reduction in VMT is identical to a reduction in eVMT though travel behavior for BEV is not the same as ICE vehicles. For PHEVs, only a fraction of the miles are electrified; in particular, the first miles of most trips. If long-range travel is reduced as the vehicle ages, this does not impact the eVMT and instead raises the effective utility factor. If, conversely, fewer trips are taken, but at a proportionally longer distance, this would lower eVMT. Additionally, battery degradation can cause the all-electric range of PEVs to decrease as the vehicle ages, which would lower the potential eVMT.
} 
reductions as ICE vehicles), the cumulative gasoline displacement and electricity use are potentially up to $5.5 \%$ lower through December 2018 .

Because all-electric range has increased since 2010, the impact of scrappage on battery capacity is smaller than for the entire vehicle. As of December 2018, only $2.2 \%$ of lithium-ion batteries in PEVs (approximately 930 megawatt-hours) will have been scrapped based on historic trends.

\subsection{COMPARABLE ICE VEHICLES}

As described in Section 2.4, the reduction in gasoline attributed to PEVs depends on the ICE vehicle that each PEV is assumed to replace. The baseline assumption in this report is that each PEV offsets the $75^{\text {th }}$ percentile vehicle in its size class, however different comparison ICE vehicles can be compared instead. Table 2 shows the impact of changing the comparable vehicle. The total eVMT and electricity consumption do not vary, but the gallons of gasoline offset through 2018 ranges from 630 million to 1.1 billion gallons and cumulative $\mathrm{CO}_{2}$ reductions range from 1.6 to 6.2 million metric tons. The lower bound comes from all PEVs replacing an ICE vehicle consuming 40 miles per gallon, while the upper bound scenario has all PEVs replace the average on-road ICE vehicle in its size class.

In Table 2, the first row represents PEVs replacing a gasoline-fueled ICE vehicle equivalent in fuel economy to the $75^{\text {th }}$ percentile vehicle in that size class for that year. The second row takes the harmonic mean of fuel economy for all vehicles in the size class for each year and uses that as the displaced vehicle. The next three rows treat all PEVs the same, regardless of size class, as if they are replacing an average ICE vehicle with fuel economy equivalent to the average vehicle sale in that year, $30 \mathrm{mpg}$, or $40 \mathrm{mpg}$, respectively. In the final row, rather than displace the purchase of a new ICE vehicle, the PEVs are displacing an average vehicle already in use when the PEV is sold.

TABLE 2 Comparison of Total Gasoline Reduction and $\mathrm{CO}_{2}$ Emissions Reduction with Different ICE Vehicles for Comparison

\begin{tabular}{lcc}
\hline \multicolumn{1}{c}{ Replaced ICE vehicle } & $\begin{array}{c}\text { Gasoline reduction } \\
\text { (million gallons) }\end{array}$ & $\begin{array}{c}\mathrm{CO}_{2} \text { emissions reduction } \\
\text { (million metric tons) }\end{array}$ \\
\hline $75^{\text {th }}$ percentile by size class [baseline] & 949 & 4.49 \\
Average by size class & $1,100(+15.9 \%)$ & $5.84(+29.9 \%)$ \\
Fleet average new LDV (EPA, 2019) & $1,032(+8.7 \%)$ & $5.23(+16.4 \%)$ \\
30 miles per gallon & $838(-11.7 \%)$ & $3.51(-21.9 \%)$ \\
40 miles per gallon & $628(-33.8 \%)$ & $1.65(-63.3 \%)$ \\
Average on-road LDV & $1,141(+20.3 \%)$ & $6.20(+38.1 \%)$ \\
\hline
\end{tabular}




\section{CONCLUSIONS}

Since the latest generation of light-duty plug-in electric vehicles have been available in the United States, more than one million PEVs have been sold, driving more than 25 billion miles on electricity. These 25 billion eVMT consumed more than 8.4 terawatt-hours of electricity while reducing gasoline consumption nationwide by 950 million gallons. Table 3 reproduces Table 1, summarizing the total impacts of PEVs by year from 2011 to 2018. Mileage driven by PEVs and electricity consumption has grown, which has offset gasoline consumption and $\mathrm{CO}_{2}$ emissions from ICE vehicles.

TABLE 3 Annual Sales of New PEVs, and Total Annual eVMT, Gasoline Reduction, Electricity Consumption, and $\mathrm{CO}_{2}$ Emissions Reduction by On-Road PEVs (Duplication of Table 1)

\begin{tabular}{cccccc}
\hline Year & $\begin{array}{c}\text { PEV sales } \\
\text { (thousands) }\end{array}$ & $\begin{array}{c}\text { eVMT } \\
\text { (billion miles) }\end{array}$ & $\begin{array}{c}\text { Gasoline } \\
\text { reduction } \\
\text { (million gallons) }\end{array}$ & $\begin{array}{c}\text { Electricity } \\
\text { consumption } \\
\text { (gigawatt-hours) }\end{array}$ & $\begin{array}{c}\mathrm{CO}_{2} \text { emissions } \\
\text { reduction } \\
\text { (million metric tons) }\end{array}$ \\
\hline 2011 & 18 & 0.1 & 2 & 20 & 0.01 \\
2012 & 53 & 0.3 & 12 & 110 & 0.05 \\
2013 & 97 & 1.0 & 37 & 330 & 0.17 \\
2014 & 119 & 1.9 & 72 & 650 & 0.33 \\
2015 & 114 & 3.0 & 110 & 1,000 & 0.53 \\
2016 & 160 & 4.3 & 160 & 1,400 & 0.77 \\
2017 & 196 & 6.0 & 230 & 2,000 & 1.10 \\
2018 & 361 & 8.6 & 320 & 2,800 & 1.60 \\
\hline Total & $\mathbf{1 , 1 1 0}$ & $\mathbf{2 5 . 1}$ & $\mathbf{9 5 0}$ & $\mathbf{8 , 4 0 0}$ & $\mathbf{4 . 5 0}$ \\
\hline
\end{tabular}

On average, electric vehicles have become more fuel efficient and have had longer allelectric driving ranges as technology has advanced. Most of the PEVs on the road were assembled in the United States. The market has begun to grow beyond the midsize and compact cars which were most common, with plug-in electric SUVs becoming more popular as models become available.

Some of the results shown in Table 3 depend on assumptions on traveler and purchase behavior. The previous report (Gohlke and Zhou, 2018) showed that different assumptions about driving behavior can change eVMT and electricity consumption by up to $25 \%$. Using alternative choices for the ICE vehicle travel displaced by a PEV yields anywhere between 630 million and 1.14 billion gallons of gasoline displaced.

More than two-thirds of PEVs have been assembled in the United States, and more than one-third of the total content is domestically sourced. Over $42 \mathrm{GWh}$ of battery capacity has been installed in PEVs since 2010, and more than 40\% of this total was in 2018. 


\section{REFERENCES}

Andre, Dave, Sung-Jim Kim, Peter Lamp, Simon Franz Lux, Filippo Maglia, Odysseas Paschos, and Barbara Stiaszny, 2015. Future generations of cathode materials: an automotive industry perspective. J. Mater. Chem. A. 3, 6709-6732. doi: 10.1039/c5ta00361j https://pubs.rsc.org/en/Content/ArticleLanding/2015/TA/C5TA00361J

ANL (Argonne National Laboratory), 2019. Light Duty Electric Drive Vehicles Monthly Sales Update. Accessed January 22, 2019. https://www.anl.gov/es/light-duty-electric-drive-vehiclesmonthly-sales-updates

Azevedo, Marcelo, Nicolò Campagnol, Toralf Hagenbruch, Ken Hoffman, Ajay Lala, Oliver Ramsbottom, 2018. "Lithium and cobalt - a tale of two commodities." Metals and Mining, June 2018. https://www.mckinsey.com/ /media/mckinsey/industries/ metals\%20and\%20mining/our\%20insights/lithium\%20and\%20cobalt $\% 20 \mathrm{a} \% 20$ tale $\% 20$ of $\% 20$ two\%20commodities/lithium-and-cobalt-a-tale-of-two-commodities.ashx

BEA (Bureau of Economic Analysis), 2018. National Income and Product Accounts. Accessed December 4, 2018. https://apps.bea.gov/iTable/iTable.cfm?reqid=19\&step=2

Berman, Kimberly, Jared Dziuba, Colin Hamilton, Richard Carlson, Joel Jackson, and Peter Sklar, 2018. "The Lithium Ion Battery and the EV Market: The Science Behind What You Can't See.” BMO Capital Markets, February 2018. https://bmo.bluematrix.com/docs/pdf/079c275e-3540-4826-b143-84741aa3ebf9.pdf

Blomgren, George E., 2017. The Development and Future of Lithium Ion Batteries. Journal of the Electrochemical Society. 164(1), A5019-A5025. doi: 10.1149/2.0251701jes http://jes.ecsdl.org/content/164/1/A5019

CARB (California Air Resources Board), 2017a. California's Advanced Clean Cars Midterm Review, Appendix G: Plug-in Electric Vehicle In-Use and Charging Data Analysis. January 18, 2017. https://www.arb.ca.gov/msprog/acc/mtr/appendix_g.pdf

CARB (California Air Resources Board), 2017b. California's Advanced Clean Cars Midterm Review, Appendix I: Alternative Credits for Zero Emission Vehicles and Plug-in Hybrid Electric Vehicles. January 18, 2017. https://www.arb.ca.gov/msprog/acc/mtr/appendix_i.pdf

Carlson, Barney, 2015. Electric Vehicle Mile Traveled (eVMT): On-road Results and Analysis. Report INL/MIS-15-34807. http://energy.gov/sites/prod/files/2015/07/f24/vss171_carlson_2015_p.pdf

Chevrolet, 2019. Chevy Electric Cars Lineu: Electric Vehicle, Plug In Hybrid. Updated January 3, 2019. Accessed January 23, 2019. https://www.chevrolet.com/electric 
Cobb, Jeff, 2018. “December 2017 Dashboard.” HybridCars, January 4, 2018.

http://www.hybridcars.com/december-2017-dashboard/

DOE (U.S. Department of Energy), 2017. Motor Gasoline Is Most Common Petroleum Product from U.S. Refineries. February 13, 2017. https://energy.gov/eere/vehicles/fact-964february-13-2017-motor-gasoline-most-common-petroleum-product-us-refineries

DOE (U.S. Department of Energy), 2018. One Million Plug-in Vehicles Have Been Sold in the United States. November 26, 2018. https://www.energy.gov/eere/vehicles/articles/fotw-1057november-26-2018-one-million-plug-vehicles-have-been-sold-united

DOE (U.S. Department of Energy), 2019. Annual Light-Duty Vehicle Sales for 2018 Totaled 17.2 Million. February 4, 2019. https://www.energy.gov/eere/vehicles/articles/fotw-1067february-4-2019-annual-light-duty-vehicle-sales-2018-totaled-172

DOE and EPA (U.S. Department of Energy and Environmental Protection Agency), 2019. FuelEconomy.gov. Accessed January 22, 2019. http://fueleconomy.gov/

Dubois, Frank, 2018. Kogod School of Business Made in America Auto Index. Accessed December 4, 2018. https://www.american.edu/kogod/research/autoindex/index.cfm

Edvardsen, Lasse, 2019. General Tesla Registration Stats. Accessed January 22, 2019. https://teslastats.no/

EEI (Edison Electric Institute), 2017. Plug-in Electric Vehicle Sales Forecast Through 2025 and the Charging Infrastructure Required. Prepared by Adam Cooper and Kellen Schefter, June 2017. http://www.edisonfoundation.net/iei/publications/Documents/ IEI_EEI $\% 20 \mathrm{PEV} \% 20$ Sales $\% 20$ and $\% 20$ Infrastructure $\% 20$ thru $\% 202025$ FINAL $\% 20 \% 282 \% 2$ 9.pdf

EIA (Energy Information Administration), 2018. Monthly Energy Review. Accessed December 3, 2018. https://www.eia.gov/totalenergy/data/monthly/

Elgowainy, Amgad, Jeongwoo Han, Jacob Ward, Fred Joseck, David Gohlke, Alicia Lindauer, Todd Ramsden, Mary Biddy, Marcus Alexander, Steven Barnhart, Ian Sutherland, Laura Verduzco, Timothy J. Wallington, 2016. Cradle-to-Grave Lifecycle Analysis of U.S. LightDuty Vehicle-Fuel Pathways: A Greenhouse Gas Emissions and Economic Assessment of Current (2015) and Future (2025-2030) Technologies. Report ANL/ESD-16/7. https://greet.es.anl.gov/publication-c2g-2016-report

EPA and DOT (U.S. Environmental Protection Agency and Department of Transportation), 2010. Light-Duty Vehicle Greenhouse Gas Emission Standards and Corporate Average Fuel Economy Standards; Final Rule. Federal Register, Vol. 75, no. 88, pg. 25324. May 7, 2010. https://www.gpo.gov/fdsys/pkg/FR-2010-05-07/pdf/2010-8159.pdf 
EPA (U.S. Environmental Protection Agency), 2011. New Fuel Economy and Environment Labels for a New Generation of Vehicles. Report EPA-420-F-11-017.

https://nepis.epa.gov/Exe/ZyPURL.cgi?Dockey=P100BAV0.TXT

EPA (U.S. Environmental Protection Agency), 2016. Midterm Evaluation of Light-Duty Vehicle Greenhouse Gas Emission Standards and Corporate Average Fuel Economy Standards for Model Years 2022-2025. July, 2016. https://nepis.epa.gov/Exe/ZyPDF.cgi/P100OXEO.PDF?Dockey=P100OXEO.PDF

EPA (U.S. Environmental Protection Agency), 2018a. Emissions \& Generation Resource Integrated Database (eGrid). February 15, 2018. https://www.epa.gov/energy/emissionsgeneration-resource-integrated-database-egrid

EPA (U.S. Environmental Protection Agency), 2018b. Data on Cars used for Testing Fuel Economy. December 12, 2018. https://www.epa.gov/compliance-and-fuel-economy-data/datacars-used-testing-fuel-economy

EPA (U.S. Environmental Protection Agency), 2019. The 2018 EPA Automotive Trends Report: Greenhouse Gas Emissions, Fuel Economy, and Technology since 1975. Report EPA420-R-19-002. https:/www.epa.gov/automotive-trends/download-automotive-trends-report

EV Volumes, 2017a. China Plug-in Volumes for Q3-2017 and October-November. Accessed June 8, 2018. http://www.ev-volumes.com/news/china-plug-in-volumes-for-q3-2017-october/

EV Volumes, 2017b. Global Plug-in Vehicle Sales for 2017 H1 + July, August Update. Accessed December 5, 2018. http://www.ev-volumes.com/news/global-plug-in-vehicle-salesfor-2017-h1-july-august-update/

Figenbaum, Erik and Marika Kolbenstvedt, 2016. Learning from Norwegian Battery Electric and Plug-in Hybrid Vehicle users - Results from a survey of vehicle owners. Report TØI 1492/2016. Institute of Transport Economics: Oslo, Norway. ISBN 978-82-480-1789-9. https://www.toi.no/publications/learning-from-norwegian-battery-electric-and-plug-in-hybridvehicle-users-results-from-a-survey-of-vehicle-owners-article33869-29.html

FHWA (Federal Highway Administration), 2018a. Developing a Best Estimate of Annual Vehicle Mileage for 2017 NHTS Vehicles. June 2018. https://nhts.ornl.gov/assets/2017BESTMILE_Documentation.pdf

FHWA (Federal Highway Administration), 2018b. Highway Statistics 2016: State MotorVehicle Registrations - 2016. November 2017.

https://www.fhwa.dot.gov/policyinformation/statistics/2016/vm1.cfm

FHWA (Federal Highway Administration), 2018c. Traffic Volume Trends: December 2017. February 7, 2018. https://www.fhwa.dot.gov/policyinformation/travel_monitoring/17dectvt/17dectvt.pdf 
FHWA (Federal Highway Administration), 2019. Highway Statistics 2017: Annual Vehicle Distance Traveled in Miles and Related Data - 2017. January 2019.

https://www.fhwa.dot.gov/policyinformation/statistics/2017/vm1.cfm

Gohlke, David and Joann Zhou, 2018. Impacts of Electrification of Light-Duty Vehicles in the United States, 2010 - 2017. Report ANL/ESD-18/1. http://dx.doi.org/10.2172/1418278

GOV.UK, 2019. Data on all licensed and registered vehicles, produced by Department for Transport. Accessed January 22, 2019. https://www.gov.uk/government/statistical-datasets/all-vehicles-veh01

Inside EVs, 2019. Monthly Plug-In Sales Scorecard. Accessed January 22, 2019. http://insideevs.com/monthly-plug-in-sales-scorecard/

Irle, Roland, 2018. Europe Plug-in Vehicle Sales for Q3 of 2018. Accessed December 3, 2018. http://www.ev-volumes.com/news/europe-plug-in-vehicle-sales-for-q3-of-2018/

IRS (Internal Revenue Service), 2009. Internal Revenue Bulletin: 2009-48. November 30, 2009. https://www.irs.gov/irb/2009-48 IRB

ITA (International Trade Administration), 2018. U.S. Imports of New Passenger Vehicles and Light Trucks, value and units. Accessed December 4, 2018.

https://www.trade.gov/td/otm/autostats.asp

Kane, Mark, 2018. "Over 50 Plug-In EVs Compared: Price, Range + More - May 2018." Inside EVs, May 21, 2018. https://insideevs.com/over-50-plug-in-evs-compared-price-rangemore-march-2018-us/

KBA (Kraftfahrt-Bundesamt), 2019. Bestand am 1. Januar 2018 nach Marken, Herstellern. Accessed January 22, 2019. https://www.kba.de/DE/Statistik/Fahrzeuge/Bestand/ MarkenHersteller/marken_hersteller_node.html

Lu, S., 2006. Vehicle Survivability and Travel Mileage Schedules. Report DOT HS 809952. https://crashstats.nhtsa.dot.gov/Api/Public/ViewPublication/809952

Mays, Kelsey, 2018. "Cars.com 2018 American-Made Index: What's the Most American Car?" Cars.com, June 21, 2018. https://www.cars.com/articles/carscom-2018-american-made-indexwhats-the-most-american-car-1420700348632/

McGuckin, N. and A. Fucci, 2018. Summary of Travel Trends: 2017 National Household Travel Survey. Report FHWA-PL-18-019. https://nhts.ornl.gov/assets/2017_nhts_summary travel_trends.pdf

NHTSA (National Highway Traffic Safety Administration), 2018. Part 583 American Automobile Labeling Act Reports. Accessed December 3, 2018. https://www.nhtsa.gov/part583-american-automobile-labeling-act-reports 
NHTSA and EPA (National Highway Traffic Safety Administration and U.S. Environmental Protection Agency), 2018. The Safer Affordable Fuel-Efficient (SAFE) Vehicles Rule for Model Year 2021 - 2026 Passenger Cars and Light Trucks, Preliminary Regulatory Impact Analysis, updated October 16, 2018. https:/www.nhtsa.gov/corporate-average-fueleconomy/safe

Nicholas, Michael A., Gil Tal, and Thomas S. Turrentine, 2017. Advanced Plug-in Electric Vehicle Travel and Charging Behavior Interim Report. Report UCD-ITS-RR-16-10. https://itspubs.ucdavis.edu/index.php/research/publications/publication-detail/?pub id=2692

NYS DMV (New York State, Department of Motor Vehicles), 2019. Vehicle, Snowmobile, and Boat Registrations. Accessed January 22, 2019. https://data.ny.gov/Transportation/VehicleSnowmobile-and-Boat-Registrations/w4pv-hbkt

OPEC (Organization of the Petroleum Exporting Countries), 2018. 2018 OPEC World Oil Outlook 2040. ISBN 978-3-9503936-6-8. September 2018. https://woo.opec.org/

Pillot, Christophe and Mike Sanders, 2017. Lithium-Ion Battery Raw Material Supply and Demand, 2016 - 2025. Presented at $17^{\text {th }}$ Annual Advanced Automotive Battery Conference, June 19, 2017. http://www.avicenne.com/pdf/LithiumIon $\% 20$ Battery $\% 20$ Raw $\% 20$ Material $\% 20$ Supply $\% 20$ and $\% 20$ Demand $\% 202016$ 2025\%20C.\%20Pillot $\% 20-\% 20$ M. $\% 20$ Sanders $\% 20$ Presentation $\% 20$ at $\% 20$ AABCUS\%20San\%20Francisco\%20June\%202017.pdf

Plötz, P., S. A. Funke, P. Jochem \& M. Wietschel, 2017. $\mathrm{CO}_{2}$ Mitigation Potential of Plug-in Hybrid Electric Vehicles larger than expected. Scientific Reports 7, 16493:2017.

https://www.nature.com/articles/s41598-017-16684-9

RDW (Rijksdienst voor het Wegverkeer), 2019. Open Data RDW: Gekentekende_voertuigen. Accessed January 22, 2019. https://opendata.rdw.nl/en/Voertuigen/Open-Data-RDWGekentekende_voertuigen/m9d7-ebf2/data

SAE (Society of Automotive Engineers), 2010. Utility Factor Definitions for Plug-In Hybrid Electric Vehicles Using Travel Survey Data. Standard J2841_201009.

http://standards.sae.org/j2841_201009/

Santos, Adella, Nancy McGuckin, Hikari Yukiko Nakamoto, Danielle Gray, and Susan Liss, 2011. Summary of Travel Trends: 2009 National Household Travel Survey. Report FHWAPL-11-022. http://nhts.ornl.gov/2009/pub/stt.pdf

Schmuch, Richard, Ralf Wagner, Gerhard Hörpel, Tobias Placke, and Martin Winter, 2018. Performance and cost of materials for lithium-based rechargeable automotive batteries. Nature Energy. 3, 267-278. doi: 10.1038/s41560-018-0107-2 https://doi.org/10.1038/s41560018-0107-2 
SEPA (Smart Electric Power Alliance), 2017. Utilities and Electric Vehicles: The Case for Managed Charging. https://sepapower.org/resource/ev-managed-charging/

Smart, John Galloway and Shawn Douglas Salisbury, 2015. Plugged in: How Americans Charge Their Electric Vehicles. Report INL/EXT-15-35584.

https://avt.inl.gov/sites/default/files/pdf/arra/PluggedInSummaryReport.pdf

Tesla, 2018. Electric Vehicle Incentives. Accessed December 5, 2018. https://www.tesla.com/support/incentives?redirect=no

Voelcker, John, 2013. "U.S.-Made 2013 Nissan Leaf Has Only 15 Percent Local Content; Here's Why." Green Car Reports, September 30, 2013. https://www.greencarreports.com/ news/1087122 u-s--made-2013-nissan-leaf-has-only-15-percent-local-content-heres-why 



\section{Argonne}

\section{Energy Systems Division}

Argonne National Laboratory

9700 South Cass Avenue, Bldg. 362

Lemont, IL 60439-4854

www.anl.gov 